Portland State University

PDXScholar

Dissertations and Theses

Dissertations and Theses

$5-22-1974$

\title{
Danish Day Care as a Social Institution
}

\author{
Albert Sessions Belais \\ Portland State University \\ Ellane L. Kibel \\ Portland State University
}

Follow this and additional works at: https://pdxscholar.library.pdx.edu/open_access_etds

Part of the Educational Assessment, Evaluation, and Research Commons, and the Organization Development Commons

Let us know how access to this document benefits you.

\section{Recommended Citation}

Belais, Albert Sessions and Kibel, Ellane L., "Danish Day Care as a Social Institution" (1974). Dissertations and Theses. Paper 2000.

https://doi.org/10.15760/etd.1999

This Thesis is brought to you for free and open access. It has been accepted for inclusion in Dissertations and Theses by an authorized administrator of PDXScholar. Please contact us if we can make this document more accessible: pdxscholar@pdx.edu. 
AN ABSTRACT OF THE THESIS OF Albert Sessions Belats and Ellane L. Kibel for the Master of Social Work presented May 22, 1974.

Title: Danish Day Care As a Social Institution APPROVED BY MEMBERS OF THE THESIS COMMITTEE:

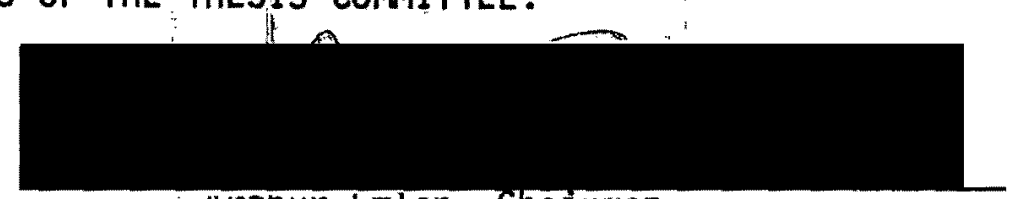

Artnur Emlen, Chairman

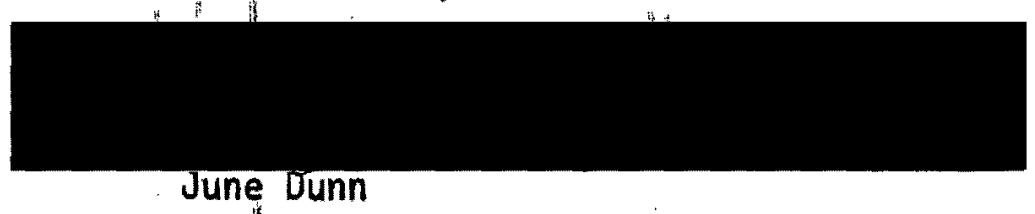

June Dunn

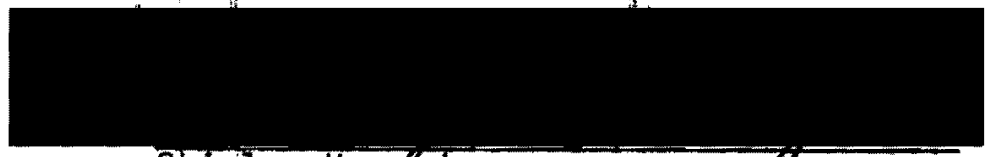

Shinley Kennedy

A study of the social and cultural aspects of day care in Denmark. The thesis hypothesizes that experiences in the development of Danish day care are relevant to the future development of day care in the United States.

Interest in Danish day care was stimulated by the reports of Drs. Marsden and Mary Wagner (1970) which found Danish day care provided an intimate and innovative standard of care for young children.

Twenty centers of widely varied types were visited in Denmark. Information was gathered largely through uns tructured in terviews with child care staff and non-participant observation. Special attention was paid to the child care workers' relationship with the children and their families. 
Attention was focused on the influence of cultural factors in the provision of child care. It was found that cultural attitudes in Denmark toward children encouraged the development of a casual, intimate style of care.

It was noted that caution should be exercised in presuming that successful Danish programs would be equally successful if carried out in the United States. It was learned that empirical evidence has convinced the Danes that the provision of an acceptable level of care is costly and that national and local subsidy is essential. Further, the coordinated system of education for child caring staff was found to provide staff capable of developing a stimulating relationship with children.

Current direction in Danish day care with other soctal service programs and the integration of age groups within centers with the attention of recreating the "family group." 
DANISH DAY CARE AS A SOCIAL INSTITUTION.

by

ALBERT SESSIONS BELAIS

ELLANE L. KIBE

A the is submitted in partial fulfillment of the requirements for the degree of,

MASTER OF SOCIAL WORK

$$
\text { - Portland State University }
$$


TO THE OFFICE - OF GRADUATE STUDIES AND RESEARCH:

The members of the Committee approve the thes is of Albert

Sessions Belais and Ellane L. Kibel presented on May 22, 1974.

Arthur Emlen; Chatrman

June Dunn

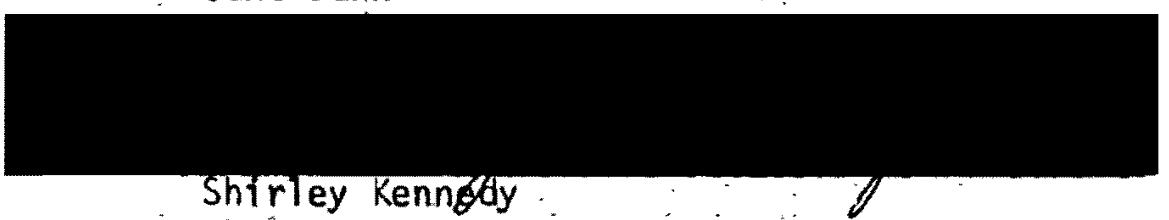

APPROVED:

Dean, School of Social Work

Dean of Graduate Studies and Research

May 22, 1974 


\title{
ACKNOWLEDGEMENTS
}

We should note that this project, carried our primarily in Denmark, has required effort and organization which might not be necessary in other projects. We are indebted first to Arthur Emlen, whose guidance, patience, and persistence ensured this project's completion.

Thanks for both moral and financial support is due to June Dunn, Director of the Child Advocacy Project at the Portland State School of Social Work; funded by the National Institute on Mental Heal th.

In Denmark, we are indebted to the administration, staff, and children of all those centers we observed for their openness and patience. We must give special thanks to Dr. Marsden Wagner, to whom we are indebted for virtually all background and historical material in this work and whose prior work in Danish day care made our work feasible.

Lastly, we would like to thank Jill Wilson, who has typed and proofread the final copy.

\author{
Albert Belais \\ Ellane Kibel
}


I INTRODUCTION AND REVIEW OF LITERATURE $\ldots \ldots . . . \quad 1$

II THE "WeLfare STATE". . . . . . . . 6

III A HISTORY OF DAY CARE IN DENMARK . . . . . ... 14

IV GOVERNMENTAL ADMINISTRATION $\ldots \ldots$

$\checkmark$ ADMINISTRATION AT THE CENTER LEVEL . . . . . . 27

VI FACILITIES ........................ 35

VII FINANCING OF DAY CARE $\ldots \ldots \ldots 4$

VIII TYPES OF DAY CARE $\ldots \ldots \ldots \ldots$

The Vuggestrue ........... 51

Dagpleje (Famlly Day Care) $\ldots \ldots \ldots$.... 58

The Børnehave' .............. . . 71

Programs for School Age Children . . . 73

The Integrated Institution ....... 78

IX THE PAEdIGOGUES AND THE PROGRAM ...... 81

X THE SEMINARIUM .................. 90

XI EDUCATION IN THE DAY CARE CENTER . . . . . . 101

XII PARENTS AND FAMILY IN-DAY CARE ......... 103 
CHAPTER

PAGE

XIII AUXILIARY SERVICES TO DAY CARE' . . . . . . . . 106

The Family Gufdance Counselor . . . . . . 106

Mother!s Help : . . . . . . . . . . 109

The Visiting Health Nurse . . . . . . 113

Child Counseling Centers . . . . . . • 117

XIV DEALING WITH POVERTY AND RACISM . . . . ..... 119

XV CONCLUSION .................... 127

BIBLIOGRAPHY . . . . . . . . . . . . . . . 132

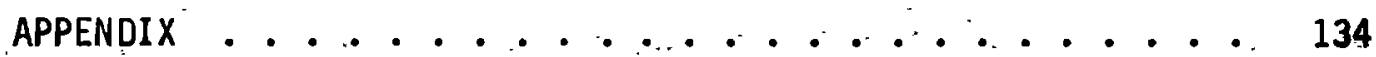


CHAPTER I

INTRODUCTION AND REVIEW OF LITERATURE

In recent years, the interest in day care in the United States has expanded immensely. During the year 1971, the federal government invested a total of $\$ 688$ million in support of day care. ${ }^{1}$ At the same time, it is estimated that matemal employment in the United States has increased to the point that one-third of the mothers of preschoolers and one-half of the mothers of school age children are employed. ${ }^{2}$

Despite increased day care made possible by Headstart and Title V-A, really major physical expansion of group day care has falled to take place. Organized group day care amounts to less than 10 percent of the children of working mothers in the United States, and fully three-quarters of the children placed in institutional care by working mothers were placed in proprietary centers. ${ }^{3}$ Mary Beth Keyserling's Windows on Day Care, in spite of lax sampling techniques, has demonstrated that there is a dismal quality of care provided in many proprietary centers. ${ }^{4}$ She indicates that the cost of quality care in proprietary centers is beyond the reach of most working mothers.

1Arthur Emlen, "Day Care for Whom?" in Children and Decent People, ed. by Alvin L. Schorr (Basic Books, 1974).

Ibid. pg. 1

3 Ibid. pg. 2

${ }^{4}$ Mary Beth Keyserling, Windows on Day Care (New York, National Council of Jewish Women, $197 \overline{2})$. 
With President Nixon's veț of the Comprehensive Child Care Act of 1971, the implementation of federal subsidy for day care on a large scale has been pushed farther into the future. The result of this situation is that money is being heavily invested in the care of a small minority of children in subsidized centers.

By contrast, Denmark is representative of a country whose system of care has developed to the point that it serves 20 percent of all children of preschool age. ${ }^{5}$ Additionally, Danish subsidies for care are distributed such that virtually all care is given government support and is, in turn, subject to government supervision and regulation. In this thesis, it is our intention to examine a national system of child care, including.both family and group care, that is already highly developed and viewed as successful.

Interest in this thesis was stimulated by the question: What relevance does the Danish system of child care have for the development of day care in the United!States? However, the research we. originally sought to undertake changed numerous times. Initially our interest was di rected at researching cross-cultural aspects of childhood aggression. - We abandoned this plan because of our lack of knowledge of the situation in which we would have to work in Denmark.

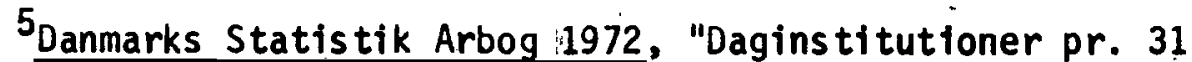
december 1972, Tabe] 1" IXXVI (Copenhagen; Soctalstyrelsen Planoegningsafdelingen, 1973), J. ne. 06/11/1-1. 
Next, the authors chose separate projects. The first project consisted of gathering participant observations of parent-child (adult-child) and child-child interactions, both in Denmark and the United States. The material was then to be compared and contrasted in search of cross-cultural generalizations. The second project was to deal with attitudes toward and the handling of aggression by adults in day care settings, both in Denmark and the United States, through the use of projective testing techniques.

When we arrived in Denmark, our initial approach toward acclimation was to visit some centers and get an orientation of the situation. After the first few centers were visited, it became evident that there was too much material available, just by visiting centers, to bypass. It was also found that the staff of the centers in Denmark were resistant to testing. Thisssituation led to the study's final format. Our purpose is to describe Danish day care as a social institution and only secondarily to consider implications for American day care.

Several factors point to the use of Danish day care as a subject of study. First, a strongly favorable report on the Danish system of care has been made by Drs. Marsden and Mary Wagner. ${ }^{6}$ Secondly, the strong emphasis placed on social issues in Danish care makes this program of interest to the field of social work.

${ }^{6}$ Marsden G. and Mary Miles Wagner, "Day Care Programs in Denmark and Szechos lovakia," in Resources for Decisionmaking in Day Care (Washington, Office of Child Development, 1971). 
Thirdly, Danish day care was more accessible to the authors than other countries, such as the Soviet Union or Czechoslovakia, in which day care is also highly developed.

One must note in advance that programs successful in Denmark may not be appropriate to conditions in the United States. Social, political, and historical conditions in Denmark differ greatly from conditions in the United States. In light of this, we consider a brief history of the day care movement to be essential to any understanding of current conditions.

The authors reviewed published and unpublished reports and visited Denmark from June to September of 1973. Information was gathered largely through unstructured interviews with child caring staff at a broad range of institutions in Denmark, as well as with administrators of Danish day care, and through participant observation. Interviews centered largely on attitudes toward the care of children in day care situations as represented both in direct care and administration. Fifteen centers, ten family day care homes, several training schools, and administrative facilities were visited. Immediately following each visit, information, impressions, and observations were written into a log, a sample of which is included in the Appendix. Statistics used are largely derived, either directly or indirectly, from data published by Denmark's Ministry of Social Affairs.

In order to fully understand the system of Danish day care, one must understand the environment in which it was developed. In the 
5

next chapter the social, political; and economic climates and their effect on the nature of child care in Denmark will be examined. 


\section{CHAPTER II}

\section{THE "WELFARE STATE"}

Together with Iceland, Norway, Sweden, and Finland, Denmark. forms part of the so-called Nordic countries, which maintain close cooperation in many fields, owing to a community of both history and. language.

Denmark has a population of close to five milition Inhabitants and covers some 16,576 sqare miles $(43,000$ square "kilometers $)$. Approximately 6 percent of the population is under the age of five years. About 70 percent of the population resides in urban areas. Almost half the population of Denmark is concentrated on the Syelland Peninsula, which includes metropolitan Copenhagen, the 1 largest city of Denmark. 7 .

Denmark is the oldest kingdom of Europe. Since 1849 the country has had a parliamentary constitution. The legislative assembly, the "Folketing," is elected for a term of four years; but writs for a general election may be issued within the four-year perlod. Women have had voting privilleges since $1915 .^{8}$ Local government is carried out through the operation of 277 local kommune counctis.

About one-half of the total Danish population is gainfully employed. of married women, about two-thirds work in their own

$7_{\text {Alfred Toft, }}$ Care of Children and Young People (Copenhagen, Ministries of Labor and Social Affairs. International Relations Diviston, 1970), p. 2.

8 IbId. , p. 3. 
homes, while one-third are employed outside the home. About 10 percent of all households with children are headed by women. Approximately 53 percent of unmarried women over the age of fourteen are economically active, 32 percent of married women, 20 percent of widows, and 64 percent of divorced women. Women comprise 39 percent of the total work force outside the bome, ${ }^{9}$ while women in the United States constitute 43 percent of the total work force. 10

Unemployment in Denmark, since the second world war, has been consistently low, about 3.7 percent in $19711^{11}$ Lack of a suffictent work force has been a consistent problem for Danish Industry. Workers imported from southem and eas tern European countries to meet the labor shortage has posed a number of problems for the Danes, who are called upon for the first time to assimtlate large numbers of imigrants. This problem will be covered in a more comprehensive form at a later point.

Denmark's productive capacity is chlefly dependent on skilled manpower and agricultural land. The largest number of gainfully employed people, 30 percent, are working in industry, 22 percent in commerce and services, and 18 percent in agriculture. ${ }^{12}$

${ }^{9}$ Statistik Arbog, op. cit., p. 57.

10 Mary C. Howell, "Employed Mothers and Their Families" Pedtatrics, LII (August, 1973), p. 252.

11 Press and Cultural Relations Dept. of the Ministry of Forelgn Affairs of Denmark, Fact Sheet Denmark. "Living Standards" (Copenhagen), p. 2.

$$
{ }^{12} \text { Toft, op. cit., p. } 3 .
$$


Taxes are levied both by the state and the kommune. Public revenue is provided through taxation of personal income and capital, land taxes, excise, and customs duties. Taxes take about one-half of the typical worker's income. The largest item of public expenditure in state budgets in recent years has been the cost of social services and public health (47. percent of taxation in 1969-70), followed by education and defense. Although old age and disability pensions account for the largest expenditures on social services, state support of child day care amounts to approximately 2 percent of all state expenditures. 13

"Cohesion but not conformity" has been described as a feature of Danish culture. ${ }^{14}$ Unlike the United States, Denmark has had a stable population for many centuries and, al though Danes take pride In their tolerance and independence, they have been hard pressed to meet the housing, educational, language, and économic demands of foreign immigrants.

During the 1970 's, Denmark's social welfare system is to be reformed and completely restructured. The special Scandinavian style of welfare state, which ensures a high degree of personal security under all conditions, is to be given a new perspective, which can be summarized in the term "preventive wel fare.".

${ }^{13}$ Statistik Arbog, op. cit., p. 56.

${ }^{14}$ Cybil Dixon, Society, School and Progress in Scandinavia (New York, Permagon Press; 1965), p. 24. 
The concept, which is new even for Scandinavia, views social welfare policy as resting upon the economic realities in Denmark and, in particular, recognizes that any increase in soctal welfare depends on high industrial productivity and the ability to compete in intemational markets. There exists a widespread notion that state welfare measures have been enacted which are beyond the financial capacity of the state.

By making increased industrial production the main tool of measurement for the effectiveness of soctal welfare policies, Denmark has put its social welfare system under completely new footing for the third time since it was generally recognized, in the closing years of the nineteenth century, that the state had a responsibility for the welfare of its citizens.

Initially, soctal welfare was considered to be little more than organized charity, and the recipient to be little more than a beggar. The first major reform, initiated in 1933, deemed that the individual had a right to welfare assistance when his circumstances indicated. This welfare policy has remained in force up to the present. $^{15}$

Recognition of these deficiencies led, in 1956, to the establishment of the Commission for Soctal Welfare, composed of thirtytwo social experts and political representatives. The Commission's conclusion was that a synthesis had to be achieved in soctal welfare

${ }^{15}$ press and Cultural Relations Dept. of the Ministry of Foreign Affairs of Denmark, Fact Sheet Denmark "Treating the Troubled Famtly," (Copenhagen), p. 1 . 
policy between the personal demands of the individual and the productive demands of the society. The recommended objective of social welfare policy was the practical question of whether treatment made it possible for the individual to function effectively in productive life. Thus, productivity is coupled closely to welfare.

To implement the new policies, the Commission recommended a completely new administrative structure that will put treatment of the individual on a local basis. Both medical and social assistance will be placed under municipal (kommune) authorities, replacing the present mixture of local and state administration. This purely administrative change will have one very important consequence: the provision of much closer coordination of all welfare activities, of which child care is a part. Spectal bodies are to be created in each locality to coordinate the welfare administration and activities and channel all assistance to the individual. At present, administration is so complicated that many social workers are not aware of all the forms of assistance avallable to their clients from state and local sources.

Welfare activities of the municipal bodies will be linked to a central coordinating body, the National Welfare Board (Socia)styrelsen), which functions as a department under the Ministry of Social Affairs.

Both social security and personal freedom are important values recognized in the Danish system of social welfare. Security, under 
the new system, will be provided by extensive rights and a broad network of institutions to provide treatment. The Ministry of Soctal Affairs budget of ten mitilion Danish Kroner is the largest allocation of any ministry, three times the amount of Danish military expenditures. 16

Studies carrled out by the 'Soctal Reformi Commisston revealed. what is termed a form of "contagion" between members of a famlly if one family member is left with an untreated social problem. Thus, wider aspects of any given social problem and the importance of treatment at an early. stage is an accepted concept.

Research validated and gave recognition to the connection between the problems facing an individual member of a family and the effect it has on all family members. In resporise to this information, the Commission made the family, rather than the individual; the focus of welfare policy.

At the present stage of Danish soclal development, the problem famtly is found to be not necessarily a poor one. Through the entire soctal range, only a slight relationship between low income and maladjustment was found; where in the past, low income and social policy almost inevi tably went hand in hand. ${ }^{17}$ p. 2.
${ }^{16}$ Fact Sheet Denmark, op. c1t., "Treating the Troubled Famlly," ${ }^{17}$ Fact Sheet Denmark, "Treating the Troubled Famtly," op. cit., p. 2. 
Social policy has thus become adapted to meet the needs of all sectors of society and raised the need for more and better trained personnel. over the past six years, family workers in Denmark have been trained in Denmark for work in close contact with child and youth welfare organizations. In the future, this service will be expanded by providing improved training for social workers and by including new material for the basic training of doctors and psychologists.

In Copenhagen, juvenile delinquency and crime is less common than in almost any other European capital, and criminologis ts have attributed this to the many youth centers that have been established. ${ }^{18}$ Repeatedly, in Interviews with individuals at all levels of the provision of child care, day care is referred to as a "preventive service," and such statistics are cited as justification for their beliefs.

Since 1945, the number of children below school age in Denmark has risen from 503,700 to 546,235 in 1971. Of these children, over 21 percent are involved in some sort of day care program, the rate being much higher in the metropolitan Copenhagen area. of these ch1ldren, 15,199 were in day nurseries, 83,123 in day care centers for preschoolers, and 17,416 were in family day care. ${ }^{19}$

$$
\begin{aligned}
& 18 \text { Ibid., p. } 2 \\
& { }^{19} \text { Statistik Arbog, op. cit., p. } 57 .
\end{aligned}
$$


In 1963 it was deemed by the state that day care should' be avallable to everyone and free to ail. "In 1963 there were places for 32,000 children in day care centers for preschoolers. The need for 30,000 additional places was forecast for 1973: In 1969 there were 50,500 chlldren in preschool day care centers; with 53,000 waiting for openings. It was believed that these figures showed a need for 38,000 more places by 1974.20 Although the construction of centers has kept pace with anticipated goals, the demand for day care has increased to the point that waiting lists are as long as at any time during the past two decades.

We may understand some of the increasied demand for day care when we consider that prior to World War. II, full day care was considered to be a service to the poor. Since the war, with the rise of taxation", many Danish. families have found that, in order to achleve a standard of living above subsistence, to share in the apparent abundance, it was necessary for both husband and wife to work. In this way, the need for day care has cut broadly across Danish society. The goals for the number of day care centers are being constantly reviewed, and it is apparent that, with a consistently aggressive program of expansion and a stable. population, the need for day care willibe met in the coming years.

20 Wagner, "Group Care," op. cit., p. 20. 
A HISTORY OF DAY CARE IN DENMARK

Denmark's history of soctal consclousness may be traced back to the catastrophical War of 1864 with Prussia and Austria. A result of this war was Denmark's focusing of attention inward toward domestic affairs: social reform, cultural expanston, dairy production; and economic elevation. ${ }^{21}$ In time, a trend toward industrialization and urbanization was manifest, as wełl as a tendency among political parties to cooperate in the improvement of the economy and advancement of society. This inward orientation exists today and may be eeflected in the fact that, al though very socially consclous, Denmark allocates less than 1 percent of $i$ ts gross national product to overseas developmental aid. 22

Over seventy-five years ago, in 1888, a law was pased in Denmark requiring that no one recelve a child, including re? atives, under the age of fourteen years in care for payment without first receiving permission from the local kommune (a designation which is translated in various sources as "township," "county," "borough," or "municipaltty," but which is essentially the local unit of

$21_{\text {William W. Brickman, Denmark's Educaional System and Problems }}$ (Washington, D.C., United States Dept. of Health, Education and Wel fare, 1968), p. 2

${ }^{22}$ Fact Sheet Denmark, "Living Standards," op. cit., p. 1. 
government). 23 The permission, which was necessary for day care in private homes as well as group centers, was revokable at any time. The law is still in effect today.

Day nurserfes themselves were inftiated in the early nineteen th century and, initially, care was provided for by "a pious, respectable woman of the lower classes" who was not required to have any spectal education. ${ }^{24}$ The first full-time day care began in 1828; the first day nursery (chlldren from birth to three years) in 1850. Day care, public and private, part day, all day, netghborhood and industrial, in private homes and public centers, from birth to age eighteen years, has been in continuous operation every since. ${ }^{25}$

The German psychologist, Frans Froebels, was the first figure to have a profound effect on the principles of Danish day care. His ideas revolved about the concept of giving an education in common to all children of preschool age, with play, imagination, and creative work as a basis. ${ }^{26}$ The first school for the training of child care workers (paedigogues), opened in 1885, bears h1s name (see chapter on Seminariums).

23 Wagner, "Group Care," op. cit., p. 1.

${ }^{24}$ Eg1l Thrane, Education and Culture in Denmark, translated by Harold Young, (Copenhagen, G.E.C. Gad, 1958) P. 53.

25 Wagner, "Group Care," op. cit., p. 1.

${ }^{26}$ Thrane, op. cit..,p. 1. 
Among the first to take up Froebel's ideas was Fru Hedvig Begger, who set up a nursery school in Copenhagen in 1880 . The movement received great impetus from the formation of the People's Nursery School Association, initiated by Fru Begger and her husband, Sophus Begger. The introduction of parish nursery schools to Denmark occurred during World War II under the leadership of Dr. R. Kier-Petersen, a local medical officer.

Danish day care was also influenced in the early part of the twentife th century by the work of Dr. Marla Montessori, who strongly emphasized the right of children to develop their capacities freely, and ascribed to education the task of giving chlldren every chance to do this.

On June 30,1919 , a program of grants to promote preventive child care authorized state grants of up to 50 percent of a large part of the running expenses of the People's Nursery Schools. The concept of "preventive services" In day care and virtually all other Danish social services is still very much a key concept in the allocation of services in Denmark today.

The program of grants to child care centers was improved upon by the Law on Public Assistance of 1935. ${ }^{27}$ Nonetheless, when in the late 1930's Denmark's Population Commission reviewed the status of non-residential child welfare centers, it found that the amount of state aid granted was far from sufficlent. (In this work, the Danish national government will be referred to as the "state.")

$$
27 \text { Ibid., p. } 50 .
$$


The financlal difficulties faced by the majorlty of centers had resulted in such low salarles that is was difficult to obtain staff of the quality required. Further, it was feared that, owing to the lack of financial support, the centers were unable to meet the santtary requirements set up by the authorities. "In a provistional report in 1936, the Commission proposed that the state grants be ralsed to cover half of the maintenance costs. ${ }^{28}$ The Commission began work on a final report on child welfare centers in which it planned to consider the demographic and social aspects of child welfare, as well as the problems of medical and dental examinations for the children attending the centers, but the report was never finished.

The Commisstion's recommendation for more financial support to the centers was not adopted, but a Departmental Committee on Chilld Welfare was set up in 1941 to continue the deliberations of the Population Commission in this field. Finally, in 1951, the increase in financial support was made permanent, after some adjustments based on the experience during the trial perlod had been made.

In 1945 the law had established a connection between the grants made by the:state and those made by local authorities, in that the amount of state aid was made dependent on the amount of local aid allocated, so that local authorities were encouraged to participate

28, Gill, "Family Welfare Measures in. Denmark, " Population Studies, VI (1952-53), p. 189. 
actively in the development of child care. The collaboration was extended by the 1 aw of 1951, whereby the local authorities were bound to make a definite grant towards the running of any child care center acknowledged by the state to be one entitled to state aid. Under both the legislation of 1951 and state building codes, grants may also be made towards the costs of establishment and building of such centers.

Since 1945, the denland for and provistion of child care in Denmark has increased rapidly until, in 1970, 9,500 children attended 260 day nurseries ( 15 percent of the total population of children $0-3$ years $), 56,000$ children attended 1,250 nursery schools (30 percent of the population of children 3-7 years), and 16,000 ch1ldren 7-14 attended 260 recreation centers.

${ }^{29}$ Toft, op. cit., pp. 25-28. 


\section{CHAPTER IV}

\section{GOVERNMENTAL ADMINISTRATION}

In Denmark, in principle the parents are responsible for the care and upbringing of their children: ${ }^{30}$

Danish law considers public intervention necessary in the interests of children in a wide range of situations. Some of the most extensive measures of support fall outside of what is generally understoond as the care of chlldren. Among these supportive measures are general education, heal th supervision of infants and school children, medical, dental, and hospltal care, and the care of physically or mentally handicapped children.

As a rule, public authorities responsible for the care of children and young people intervene only where and only, to the extent that the parents are unable to provide for their well being. The broad scope of services deemed necessary to the heal thy development of children, however, necessitates public involvement with children and their famflies. An example of this is the fact that the state provides children's al lowances to any family with children. Other services will be discussed later in a chapter concerned with auxiliary services to child care.

Denmark's system of child advocacy has evolved empirically over a period of many decades. The responsibilities, powers, checks, and balances have been gradually modified over. time, based on their

$30_{\text {Ib td. , p. } 1 .}$ 
experience, through changes in the law. The last major reviston was the Children and Young Persons Act of 1964. This law is the basis of all child care pollcy in Denmark. The main directive of the act states that: "The purpose of the relevant care is to ensure that children and young people grow up under conditions likely to promote a sound mental and physical development." 31

Underlying this law is the generalized attitude that a child is innocent, good, and born with a "clean slate." Reflective is the fact that in Denmark no child under the age of fifteen can commit a crime; he can only make a "mistake." It is assumed that if he does make a mistake, it is almost certainly the result of a poor environment. As a consequence of this, a child who makes a mistake is taken not to the police but to the Child and Youth Comittee of the kommune (to be discussed subsequently) as demonstrating a symptom of possible poor living conditions for the child which must be corrected. ${ }^{32}$ In serious cases, where conditions in the home cannot be remedied, the child will be removed to a foster home.

The mistake the child made may range from shoplifting to murder. The legal rights of the child do not allow him to be tried. All efforts are directed at his home environment to seek to make appropriate changes. (Larger apartment, homemaker, etc.)

31 Ibid., p. 5.

32 Mary G. Wagner and Marsden G. Wagner, "Child Advocacy in Denmark: 70 Years of Experience with This "New" Idea" (Washington, Office of Child Development), p. 6. 
In Denmark there exists no correlate to juvenile detention homes for "acting out" youths. Youth homes are beginning. Youths who are unhappy at home can voluntarily move into a home. These homes provide a very adequate room, board, and some spending money. When the youth chooses to leave, he may do so.

The state of Denmark is responsible for the passing of laws outlining the type and scope of services to be offered to the people. The laws also specify how the funding of these programs will be shared. The administrative departments are then given the task of supplementing these laws with bulletins, which make recommendations with regards to the practical implementation of the laws. The operation of the programs themselves is entirely the responsibility of the local kommune.

The Ministry of Soctal Affairs is the national administrative department that is given the responsibility for developing plans to Implement the laws regarding day care through policy making. standard setting, and general surveillance. Spectfically, the Child and Young Persons Act of 1964 states that the Ministry of Soclal Affairs shall be responsible for establishing regulations concerning:

1. The layout, conduct, and running of the institutions.

2. The educative work to be carried out in the institutions.

3. Medical attention and dental care.

4. Salaries, pensions, and other conditions of employment for persons in charge and members of the staff. 33

33Ibid., p. 10. 
The Ministry is legally obliged, through the Department of Child and Youth Affairs. within the Ministry, to inspect every day care facility twice a year to ensure that these regulations are enforced. Ten inspectors have been given the responsfbility for conducting these inspections throughout Denmark, so unfortunately, inspections are generally made only where there is reason to expect that a center is not meeting state standards or is experiencing difficul ty in operation. Inftially, these inspections were primarily concemed with health and safety regulations and physical facllities... Recently, new emphasis has been given to the development of programs and human aspects of the centers concerned; 1.e.. how to handle a child.

- Under new laws, many responsibilities currently assigned to the Ministry of Social Affalrs will be transferred to the local kormunes under a program of decentralization. Inspections and the establishment of standards in such areas as staff-to-child ratios will become the responsibility of the local authorities.

Practically speaking, since the turn of the century the primary responsibility in the field of chlldren and young people has been exercised at the local level in the form of the Kommune Child and Youth Welfare Commttee. ${ }^{34}$ The present extent of the powers and responsibllities of this committee in child and youth affairs generally, and child care spectfically, are extraordinary.

34 Wagner, "Child Advocacy," p. 10. 
The population served by the Criild and Youth Welfare Commlttee of the Kommunes varies between about 1,000 and some 130,000 persons. In Copenhagen, where the Child and Youth Welfare Commlttee serves over 700,000 inhabitants, "modified rules and procedures necessary to cope with the large population served are exercised:

Every four years, each kommune elects a council (roughly. equivalent to a city council or county board of supervisors). One of the elected council members with a special interest in children becomes the chalrman of the Child and Youth Welfare Committee and is jolned by two (or three) more kommune council members who volunteer for the Committee. The council then chooses two (or three) local citizens to form a committee of from five to seven members. Among the several important features of the Committee are: 1) A majority of the Committee members are elected counctl members; 2) All are "lay" people with interest but no spectal training for this work; 3) There must be both men and women on this Committee; 4) There Is no pay for this work aside from expenses; 5) All are volunteering their time; 6) The Committee is reformed every four years; and 7) The Committee is not subordinate to the kommune but carries out its activities as a separate unit. 35

The Child and Youth Welfare Committee reports to the Kommune Council. The Committee derives its legitimacy from the Ministry of Social Affairs.

35 Ibid. , p. 10. 
The local Child and Youth Welfare Committee may meet oniy two or three times a month. It is the Commlttee's professional staff which carries out the ongoing responsibilities under the direction of the Committee. The staff includes, where feasible, social workers, and has secretarial assistance. The size of the staff varies depending on the individual kommune. The staff is hired and fired by the Kommune Council itself.

In addition to the Committee's regular members, specialists may be co-opted. For example, considering removal of a child from his home against the parents 'wishes, a judge and an educational psychologist appointed by the Ministry of Family Affaitrs, are co-opted. Their assistance may also be sought in other circumstances. The specialist is from government service, and part of his time is (can be) spent with the Child and Youth Welfare Committee. The personnel of the Directorate of Child and Youth Welfare Services include fourteen regional child care advisors, who assist the committees in the general organization of their work, as well as in the handling of individual cases. These co-opted members have no voting privileges in the Commtttee.

The attention of the local Child and Youth Welfare Committee is directed along two 1 ines. It is responsible for rendering assistance not only to particular children and young people but is also responstble for taking initlative in more general measures. The Committee is also responsible for ensuring that there exists a 
sufficient number and variety of day care institutions and recreational facilities in the kommune. If necessary, the Committee makes recommendations to the kommune to remedy defictencies. It is the duty of the kommune to establish and maintain the necessary institutions where the need cannot otherwise be met. ${ }^{36}$

Housing developers must appear before the Commlttee to establish not only that a proposed development includes adequate day care facilities, but that children have been taken into account in the overaill planning, including architecture, traffic patterns, parks, play areas, and business development.

Thus, the Child and Youth. Welfare Committee becomes involved in the "community as a:whole." It is involved not oniy in cases where there is a need for assistance to a particular child or family, but also where it is necessary to take the initlative in more general measures. The Cormittee ensures that there exists a sufficient variety of day care institutions and recreational facilities of a social and educational nature. If necessary, the Commi ttee makes recommendations to the local council to remedy deficleacles. Additionally, any person or group, professional or lay, who feels there is a need for more day care or some change in existing day care services is obliged to report this to the Committee.

We may note at this point the implied sense of "duty" on the part of every member of the community, not only to support existing ${ }^{36}$ Toft, op. ctt., p. 30. 
facilities, programs, and planning for children, but to bring deficiencies to the attention of the Committee. It is also worth noting that, in spite of the extensive duties and responsibilities of the Committee and its voluntary status, there is no shortage of volun teers. 37

37 Wagner, "Child Advocacy," op. cit.,"p. 4. 


\section{CHAPTER $V$}

\section{ADMINISTRATION AT THE CENTER LEVEL}

One of the most basic concepts in Danish day care is that private day care for profit is 111 egal. ${ }^{38}$ This law is a product of the feeling that: (1) Day care should be a social and not a business transaction. Day care is seen as a developmental necessity and should not become simply a babysitting service. (2) Day care of the quality desired is financially impossible without government support for all but a few well-to-do families. (3) The proflt motive will only serve to undermine the quality of care provided.

There exists, therefore, only a small handful of day care centers which are privately owned and operated without govemment subsidy. These centers serve a few children of upper income families. They are not allowed to operate as profit-making institutions and must meet all state standards. This is the unusual meaning for private day care.

The terms "private" and "municipal" day care in Denmark carry a special connotation. A "private" day care center is usually operated by a group of individuals or, as in most cases, by a nonprofit organization. It has its own board of directors selected from the community and determines its own pollcy within the state guidelines but receives essentially the same financial assistance as a "municipal" day care center.

38 Wagner, "Group Care," op. cit., p. 4. 
The municipal center is proposed to the Child and Youth Welfare Comittee by a lay person who has knowledge of a need for day care or by the Committee itself through its own investigations. The local Child and Youth Welfare Commlttee acts as the board of directors for the municipal center, and psychologists and other professionals utilized by the Chlld and Youth Welfare Committee are generally avallable to the municipal center for consultation.

There also exists a third type of center which is leader owned. These centers are actually survivals from the early twentieth century mode when such centers were the dominant form of care. At present, there are only a few such centers, and their numbers are dwindling. These leader-owned centers are allowed no profit, and the salary which is allocated to the leader is strictly controlled. Leader-owned centers are discouraged, and the possibility of profit is controlled by $11 \mathrm{mlting}$ the enrollment at such centers to a maximum of twenty chlldren.

Generally, the differences in outward appearance and operation of the two predominant (private and muntcipal) types of centers are quite mintmal and, indeed, the distinction between such centers is often little more than a technicality. Municipal centers are, in general, more 11kely to receive extra subsidies from the kommune in order to support chlidren from low income famllies and spectal programs or problem situations. The private center, in turn, is less subject to scrutiny and control by the komiune. The more radical private centers (communist and Marxist orientation, for example) prefer the 
freedom in program and design which may be exercised under a private program. It must be noted that many of the most radical centers in terms of design and philosophy were municipal. At a later point, the Hundegarten center will be discussed. It is a center based on radical and Maoist thought, which is municipally operated.

The role of the director in a Danish day care center differs from the director in most day care centers in the United States. Instrumental in this is the control of the size of Danish centers. VIrtually all centers observed served fifty children or less. Upon locating the first day care center we were to observe, we were dismayed by the fact that we were unable to find the "main entrance" to the center or any indication of where adminis trative work was performed. After several attempts, we found the director mopping the floor in the staff lounge.

We were initially impressed with the amount of time that the director was able to spend with the children. It was learned subsequently that the director of a center is expected to devote 50 percent of his or her time in direct work with the children. Only one center observed had any sort of clerical staff on the premises. It was later learned that most secretarial and billing responsibilities were handled at a central office. The director of the individual center is responsible for preparing a budget for the center, according to prepared guidelines. These budgets are checked both by local and state authorities. Many of the problems of budgeting are al leviated by the stability of 
financial assistance in this system. Day care centers experience little doubt as to the financial solvency of the center.

Medical records are kept, but they are brief, and any suspected problems are referred directly to the child's physictan. Aside from attendance records, little information is comptled on the children and, hence, recordkeeping is minimized.

One may see that the director of a Dantsh day care center is given ample opportunity to develop a relationship with the children, their parents, and staff.

Generally, the position of director in a Danish day care center holds 11 ttle more status than that of a fully-trained child care worker (paedigogue). The salary. is about 10 percent more than that of the paedigogue, but most prefer the greater contact with the children to the administrative responsibilities. Few directors receive the one-year special education; aside from that received as a paedigogue. The result is that some centers experience difficulties in recruiting a director. At a few centers, experiments are taking place with a rotating directorship with all paedigogues taking on the responsibilities in turn. This experiment has met with mixed success, depending on the attifudes of the paedigogues involved.

The aforementioned categories of center cannot do full justice to the types of day care offered. For example, one type of day care experimented with in recent years has been the Industrially located center. This type of center was inttlated primarlly for the benefit 
of large employers and their employees. Denmark has experienced a shortage of workers for a considerable period of time. Some large employers felt they could draw in workers by having day care centers located on the plant site. A prime consideration here, from the social standpoint, was that mothers would be able to visit their children during break periods. Additionally, the contribution of the employer to the finances of the center would lower the cost of care to the parents. Al though such industrial centers do exist today, they have generally fafled to meet the anticipated benefits.

It was soon discovered that women employees with children in the industrial center were simply unwilling or unmotivated to give up their break time. We were told by the director of one such center that virtually no mothers have ever visited their children at the center. Also anticipated as a benefit of the industrially located care was the ease with which the mother would be able to leave her child at the center without detouring to a day care center on her way to work. But many mothers commute by either bus or bicycle, and this necessitated a long ride very early in the morning, often through cold, wet weather which predominates during Denmark's long winter. Thirdly, it was found that children placed in a local neighborhood center, as opposed to an industrial center, were able to leam more about their own community and were able to establish relationships with children whom they were able to see during weekends and after the centers closed. Aligned with this fact is the problem that industrial day care is more difficult to coordinate 
with the other extensive soctal services dispensed from nelghborhood centers. Finally, and certainly one of the most significant findings of the experience with industrial day care, was that industry was generally efther unwilling or unable to cope with the problem of day care. ${ }^{39}$ Friction developed between the company and employees over day care arrangements, particularly over children placed on watting lists. Al though initially it was understood that industry financed the bulk of the cost of care not subsidized by state and kommune sources, an industrial day care center we observed, operated by a large brewery, was found to receive only 54,000-57,000 Danish Kroner (approximately $\$ 9,450-\$ 10,000$, based on an exchange rate of 5.7 Danish Kroner to the United States Dollar) per year. Al though the annual operating cost of this center was not available, one must assume that this amoung could not account for 30 percent of the ongoing operating costs of a center serving fifty children. It was further noted that the cost of care to mothers at this center was higher, not lower, than the cost of other centers observed. One is led to suspect that among the major fallings of the Industrial care centers was the fallure by parents and industries to utilize the center in an innovative manner. Experimentation is being conducted at some centers with twenty-four-hour availability of care for children whose parents work at night. The center, serving an industry which operates on:a full-time basis would seem

$$
{ }^{39} \text { Ibid. , p. } 8 .
$$


to be a logical choice for experimentation with twenty-four-hour care. Although this was suggested to the company by the center's staff, no funding was provided.

At this time, industrially-operated centers are still operating and have, like most centers, long walting lists. Although there are numerous disadvantages as previously mentioned, industrial day care does provide a good and convenient altemative for many workers. Industrial centers do open earlier (the same time as the morning work shift begins), thus eliminating the problem of time coordination between parents' work schedules and non-industrial day care center schedules. Newer centers are being located principally in local neighborhoods. In total, industry has found that they are not competent to act as providers of services such as day care.

At present, parents wishing to obtain child care apply directly to the center desired. Unfortunately, in spite of ambitious plans to fully meet child care needs in Denmark, it was found that all established centers observed had walting lists which contained as many children as the centers themselves. Many centers are actually over-enrolled, as directors have a particularly difficult time in turning away children in particular need of care. These waiting lists are, however, misleading. Most parents apply at several different centers, often before the child is born. In the near future, watting lists for chlld care will be coordinated at a local social service center. This will both serve to give a more realistic picture of the extent of need for child care and serve to ensure 
that high-priority, high-need children are placed in the first àvailable openings.

In summary, there are four different types of day care avallable in Denmark: municipal, private, leader owned, and industrial. The most prevalent is the municipally-operated center, followed by the private center.

The role of the director of the center is different from the United States director. The duties require 50 percent of the director's time to be spent with the children.

The new trend in day care is to keep the child within his neighborhood. The experience with industrial day care helped the "Danes recognize the benefits of children staying in their own kommune. 


\section{FACILITIES}

In the previous chapter, allusion was made to the rapid expansion of group care in Denmark since the end of the second world war. This growth may, in part, be attributed to increasing rates of maternal employment and increased interest in the basic issues in child development during the preschool years. None theless, this accounts only for the increased demand for care and not for the increased number of actual avallable places in day care centers. The physical expansion of day care facilities has been brought about through ambitious govemment legislation in financing the construction of child care' centers.

Ninety-five to 97 percent of the cost of construction of child care centers may be obtained through outright grants and primary and secondary loans subsidized by the state. ${ }^{40}$

The local Child and Youth Welfare Committee is responsible 'for ensuring that adequate facilities exist for children in each neighborhood. A result is that the developer proposing new construction must demonstrate that the needs of children have been taken into account in planning. To meet this need, developers may not only subsidize the construction of day care facilities and recreation facilities but contribute to the ongoing cost of operation.

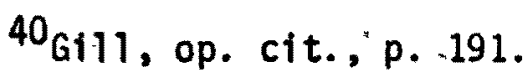


in some cases up to 30 percent, or virtually the entire nongovernmentally subsidized cost.

Although the size and location of most centers vary widely, the Danes have found through experience that the optimal center is: (a) located in the immediate neighborhood of the potential users and (b) small in size. ${ }^{41}$ The reasons for neighborhood location have been discussed previously. In regard to the industriallylocated center. The Danes have found, again simply from experience and not research, that the day nursery should have no more than fifty children. ${ }^{42}$ This experience would appear to be consistent with the findings of Prescott, et al, that raise questions about large centers. $^{43}$ This rule, however, does not hold fast, as centers of up to 150 children were found operating smoothly, due to innovative architecturat techniques.

Most chlld care centers are bullt on the same site as facilities for children of differing age groups. Each facility in a site is Independent but cooperative. In attempting to maximize the utilization of each facility, many serve one purpose during the day and another at night. Because of the specialized design of factlities

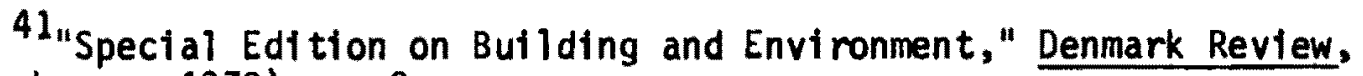
(Copenhagen, 1972), p. 2.

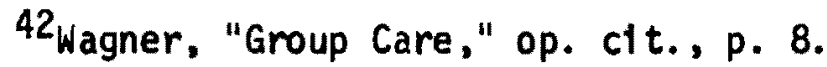

${ }^{43}$ Elizabeth Prescott, Day Care as a Child Rearing Environment, (Washington, D.C., National Assoclation for the Education of Young Ch1ldren, 1972). 
for younger children, it is generally the factlities of adolescents that serve multiple purposes. The most common example of this is the facility which serves as a senior citizen's center during the day and a youth recreation center at night.

Throughout their building programs, the Danish government has relied on private enterprise for the development and construction of these centers. Architects and psychologists have combined with a highly-developed bullding industry to offer primarlly prefabricated facilities at low cost. of the centers observed, only a small minority were operating out of factlittes not expressly designed for use as a child care center. Of that minority, one was located in a former veteran's facility which had been extensively remodeled for its current use. Another, operating out of vintage World War II anmy barracks, was scheduled for relocation into new facilities in the near future.

When any new day care institution is to be built or an old one remodeled, the plans must be submitted to the Ministry of Social Affairs for approval before financing can be secured. The state review includes evaluation by: (1) professionals in the day care field to ensure that the social and educational needs of the children will be met by the plan; and (2) engineers who ensure that the regulations with regard to floor space (six square meters per child in the preschool centers and ten square meters per child in the day 
nursery) and safety regulations are met. They also ensure the plan will not be excessive in cost. 44

Experimentation has been taking place over the past several years in altering the traditional "classroom" type of design with spectal emphasis on abandoning rigid designs in favor of designs which allow for flexible use. The Ki Ta Dan System is utilized in over two hundred day care centers in Denmark. It was developed at the suggestion of the Danish Ministry of Soctal Affairs to meet the need for a day care' center which could be erected, moved, and al tered quickly and conveniently to meet the changing economic or program requirements. The heart of the system is a single building with space for fifteen to twenty children. New wings may be added, as needed, to the basic element. Changes can be made within the unit; all walls, heating, and plumbing can be altered according to climatic specifications.

The design of these units was the result of extensive research and experimentation over a number of years, utilizing the principles which have developed into the Danish 11 festyle and style of child care. Although Danish winters are long, cold, and wet, there exists a strong belief in the value of extensive outdoor activity. As our observations took place during summer months, virtually all of the activity was conducted outside. We were told that, even during the

${ }^{44}$ Gill, op. cit., p. 189 . 
most severe winter months, the children are clothed heavily and allowed to play outside for extended periods of time. These beliefs have resulted in an indoor-outdoor type of construction. The "open" design of most centers is such that children can be free to move from room to room, yet still be readily observable by the staff.

Since it was generally felt to be beneficial for children of various ages to mix with each other, common play yards have been designed. Until quite recently, different age groups had separate wings or suites within each center. This practice is being phased out slowly in every preschool center observed. A later section has been devoted to the logical conclusion of this idea, the "integrated" institution, in which children from infancy through adolescence are combined in one facility and divided not into age groups, but "family units."

Within the basic unit, each group of children has a suite of rooms which will generally consist of an all-purpose room (often with a folding partition to divide the room when appropriate), a workshop, toilet facilities, eating area, and possibly a kitchen shared with another suite.

Each child has his own marked locker, towel, clothes, bed, and so on. These are marked by his name embroidered on towels and clothing if he can read, or a picture symbol which becomes his identifying mark. The locker area is generally quite large, with sufficient room for changing many layers of clothes or diapers and still allow ample space for the staff to converse with the parents 
during the process of changing. A small director's office is also available for meetings with parents, as well as numerous other functions. Children suspected of developing 11 lness, or who need temporary removal from the group for social or psycholotcal reasons, are placed In a small isolation-observation room.

Extended contact with these centers causes the observer to be impressed by the obvious care which is taken to design the facilities on a scale appropriate for the age group being served. Not only is furniture small scale, but such 1 tems as light fixtures are of threequarters normal size and hang low enough that taller adults must take care in negotiating their way about the room. The advantages of constructing a center expressly for child care were noted by a staff member of a facility that had been extensively remodeled for $i$ ts present function. Al though the furniture was of appropriate size, the rooms were large with high cellings, and the staff members had encountered problems, espectally with younger children, who, awed by the size, retreated to secure positions underneath tables, in closets, and the like.

The Danish day care center includes a number of safety features. They are built on one level; door hinges have strips of plastic covering the openings; the lower half of the door consists of shatterproof glass so that an adult can look to be sure that no infant is on the other side before opening the door; and water heaters have an attachment which prevents the water temperature from rising high enough to burn or scald a child in the butlding. 
Upon entering any particular suite of rooms, one is inclined to evaluate the area as anywhere from simply cluttered to extremely messy. Toys are everywhere, a maze of mobiles hang from every ceiling, and paintings cover every avallable bit of wallspace. The room is, in fact, a creation of the children themselves.

After spending a great deal of time in American day care centers arbitrating feuds over the use of one bicycle which must suffice for several children, it was almost amusing to witness battles, though relatively infrequent, over the use of one tricycle when there existed almost one tricycle for every child at the center. Each center had tricycles of all shapes, sizes, and designs, from ones which supported infants barely able to walk to rather elaborate affairs with detachable trailers. The problem of sharing toys in an environment where there was a plentiful supply for all took on new meaning. It was a problem inevitably solved by the simple suggestion by a staff member that other toys of the same type were readily available. The great number and variety of toys makes independent forms of play more accessible for each child in the center. Dependency on staff to provide sources of activity is minimized.

Outdoor play equipment is almost universally handmade and constructured of rough logs. Swings in each center observed were of the old tire type. It was said that this type of swing is the least prone to injury of children. The two breweries which combine to produce virtually all of the beer consumer in Denmark recently switched from wooden crates for the distribution of their beer to 
plastic ones. The older wooden crates were made available at a nominal cost, and most day care centers seem to have taken advantage of these cases to construct open-ended and free-form structures which serve as the basis for much outdoor play.

Play equipment in the centers is designed to allow cooperative play but, at the same time, designed in such a way that no child is ever put at the mercy of another. In line with this, it was pointed out that play areas do not include teeter-totters, due to the possibility of a child deciding to get off while the other child is suspended in the air.

In spite of this, dangers to children have not been completely eliminated from the day care centers. We were initially surprised to find a wrecked car located in a remote area of one of the centers. In discussing this with a staff member, it was said that children must learn to live with dangers which are inherent in living in the city and that, al though more lethal dangers of the car had been removed, they had no intention of removing the car. In observing subsequent centers, more cars were found and similar attitudes on behalf of the staff. When the parents' attitudes towards these dangers was questioned, it was said that parents were accepting of the practice and had not held the staff to blame for few ensuting injuries.

In conjunction with the construction of day care centers, the local Child and Youth Welfare Committee is also responsible for the assurance of sufficient playground facilities, both supervised and 
unsupervised. The population density of Copenhagen has provided a particular problem in meeting this need. Among the innovative ideas that have been uttlized in meeting this need has been the construction of playgrounds located behind older apartment buildings. To achieve this, miscellaneous structures located behind apartments have been removed and the area consolidated with that of adjacent apartments to form an open core in the center of a block of apartments. This open core can then be turned into a playground and community area. We were not able to ascertain the exact number of such playgrounds but were told there are "many." Potentially, each block of apartments could conceal a playground in its core. 


\section{CHAPTER VII \\ FINANCING OF DAY CARE}

Possibly among the most surprising aspects of the Danish system of day care is the extensive public subsidy amounting to over seventeen billion Kroner ( $\$ 300$ million) yearly. 45 Total federal substdy of day care in the United States amounted to $\$ 688 \mathrm{milli}$ ion during the year 1971. 46 The Danes appear to be well aware of the expense involved in providing day care of the quality desired and consider it to be a sound investment.

Public subsidy of day care is present in virtually all aspects of the system of care. In construction of new day care facilities or additions to existing ones, low-cost loans are avallable both from private resources and from the state. ${ }^{47}$.

Property expenses of day care institutions, including rent, interest, tax, Insurance, and maintenance relating to real property is fully subsidized by public funds, of which four-sevenths is allocated by the state and three-sevenths by the local kommune. ${ }^{48}$

${ }^{45}$ Statistik Arbog, op. cit., p. 48.

46 Arthur Emlen, "Day Care for Whom?" in Children and Decent People (New York, Basic Books, 1974), p. 3.

${ }^{47}$ Ministry of Social Affatrs of Denmark, "The Child and Young Persons Act of 1964" (Copenhagen) Sec. 65, p. 19 .

${ }^{48}$ Ibid.., p. 20. 
Other ongoing operational costs are partially subsidized by public funds. The infant day nurseries and preschool child care centers receive 35 percent of approved expenses from the state and 30 percent from the kommune. Recreation centers, playgrounds, and other recreational facilities receive 40 percent of ongoing operational costs from the state and 35 percent from the kommune. Recreation clubs and youth clubs receive 45 percent subsidy from the state and 35 percent from the kommune. 49

Medical examinations must be given to all children involved in a day care program under the age of one year every three months, and those over the age of one every six months. The entire cost of this mandatory program is subsidized by the state.

In the case of day nurseries and preschool day care centers, the system leaves 35 percent of ongoing operational expenses to be derived from other sources. In a large number of centers, fees paid by the parents on a sliding scale basis according to parental income covers the remainder of the expense. In centers with industrial locations, the company will generally make some contribution: Housing developers usually make some contribution to the expenses of centers located in new developments. Gifts and contributions account for less than 1 percent of operating costs. 50

Finally, the kommune is obliged to provide for a number of "free spaces" for needy families and may further subsidize the center above

49 Ibid. , p. 21

${ }^{50}$ Statistik Arbog, p. 54. 
its obligated amount or, in some cases, make allocations directly to low-income families to cover the cost of care.

A few institutions which have special problems in financing may receive additional funds from the state. An example of this type of institution would be a day care center observed that was housed in crowded, former army barracks. The center was provided with funds for an extra staff member to cope with the children in crowded conditions and additional funds for maintenance of the older building. Institutions may, under certain circumstances, be eligible for full payment of operating costs, after deduction of receipts, within the $1 \mathrm{imits}$ of a budget previously adopted by the National Board of Soctal Welfare, of which four-sevenths is allocated by the state and three-sevenths by the kommune. Arrangements such as this are primarily intended for centers serving handicapped, disturbed, or retarded chlldrea. 51

Danish authorities have, until recently, felt that it is important for a family to contribute financially to the cost of care for their children, even if this amount is nominal. It is with this principle in mind that allocations are made directly to some needy famtlies for care rather than making an additional allocation to the center. The government subsidy of day care institutions was established by the Child and Young Persons Act of 1964. In 1966, the Ministry of Social Affairs set the guidelines

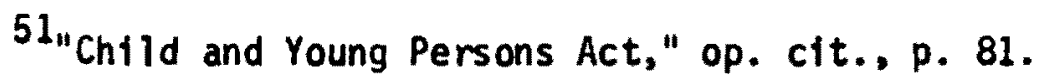


for current parental contributions. Parents with gross incomes of over 40,000 Kroner (s1ightly over $\$ 7,000$, based on an exchange rate of 5.7 Kroner per Dollar) per year pay the "full" fee, accounting for the unsubsidized 35 percent of the total cost of care. Parents with lesser incomes pay 25 percent or 50 percent of the "full" fee or, where the parents' income is below 20,000 Kroner per year, recetve free or fully-substdized care.

"Ful1" fees at centers observed during the course of this study ranged from 45 to 91 Kroner $(\$ 7.89$ to $\$ 15.96)$ per week per child in the day nursery and 35 to 67 Kroner ( $\$ 6.14$ to $\$ 11.74)$ per week per chlld in the preschool care. After school clubs and recreation centers have one price for all. This is generally only a nominal sum, as additional financing is derived from the kommune or private sources. In centers observed, the range of cost was from 20 to 42 Kroner ( $\$ 3.57$ to $\$ 7.37$ ) per week in after school clubs and 10 to 100 Kroner $(\$ 1.75$ to $\$ 17.50)$ per month in recreation centers. 52 Spectal rates are applied for families with more than one child in care.

In principal, the Danes feel that financial considerations should not come between the parents of children in care and the staff of the center. For this reason, payment of fees in kommune-operated centers is generally made directly to a central office or simply passed on to the office by the day care center. We felt this to

${ }^{52}$ See appendix. 
be a heal thy practice. The staff remained uninvolved in all financial matters. Both staff and parents seemed to prefer this method of payment, which aided in eliminating discomfort over financial status.

Each day care center prepares its own accounting report. This is submitted to the local Child and Youth Welfare Commlttee for review. It is also received by a local accountant not connected to the Child and Youth Welfare Committee in any way. It is then submitted to the state, where it is reviewed by centralized computer accounting procedures. A fixed tolerance for deviation from established expense norms is set, and institutions which deviate beyond these norms are investigated to determine why. The computer is also used to project future cost estimates for use by the kommunes and institutions, as well as the state.

Due to the complex system of subsidies, differences in living costs, lifestyles, and the recent wide fluctuation of both the United States Dollar and the Danish Kroner, the true cost of day care in Denmark is almost impossible to determine; however, in the fiscal year 1969-70, 17, 184,400,000 Kroner (slightly over $\$ 300,000$, 000) was allocated to the support of day care in Denmark. Of this amount, 230,700,000 kroner was derived from state funding, and $186,600,000$ was from local sources. 53

${ }^{53}$ Statistik Arbog, op. cit., p. 58. 
Of somewhat more importance to the functioning of day care in Denmark is the fact that this system of financing is relatively stable. None of the centers studied perceived themselves to be in any danger of losing funding. No parents worried about having to find a new center for their child should the center the child is currently enrolled in be forced to close. . No staff members are given any cause to doubt that they would be paid regutarly. The importance of the psychological effect on all thosê persons involved in this stable system of subsidy cannot be underestimated. 


\section{THE TYPES OF DAY CARE}

To this point, centers have been referred to in such terms as the "infant day nursery," "preschool day care centers," and so on. In previous chapters, material has generally referred to aspects common to all forms of care. In this chapter, the types of centers will be broken down and individual types of care discussed.

\section{THE VUGGESTRUE}

The infant day nursery (or creche) will be referred to as the "vugges true" (plural, "vuggestruen"). The ideas behind the vuggestrue should be distinguished from programs in other countries which serve the infant from birth to the age of three years.

The Banes found that one of the most important keys to the success of provision of care at all age levels was the provision of adequate staff. The vuggestrue is divided into three age groups, each with its own staffing ratio and specialized setting.

In the youngest group (age two to ten months), a child-to-staff ratio of four to one is mandated with an optimal ratio of two to one during play and eating periods. In the second group (age ten to eighteen months), the child-to-staff ratio is five to one with an optimal ratio of two and one-half to one during eating and play. The oldest group has a mandated ratio of ten to one and an optimal 
ratio of five to one during eating and play. ${ }^{54}$ Much of the time spent in observation for this study was during the months of July and early August when most Danes take their vacations (a full month's vacation is standard). During this period, it was found that virtually all of the centers observed were operating with a child-to-staff ratio of two to one.

The vuggestrue 1 tself is divided, in most cases, into three suites. For the youngest group of children, a sulte consists of two primary rooms equipped with cradles or bassinets suspended from the celling so that they may be gently and easily rocked. Cradles, perambulators, and any other places where a child spends a good deal of time, are equipped with colored mobiles in primary colors and basic shapes. Bottles filled with colored water and other visual stimulae are placed about the room.

As soon as a child is able to crawl, he is put efther on a large pillow or a soft mat on the floor. He is then surrounded with soft toys which, again, are colorful and shaped in various ways. There is a seemingly endless variety of toys to creep into, push around, pull, and roll, as well as swings, floor walkers, and pillows to prop up immobile children in order that they may be able to view what activity is going on around them.

The toys that are available to a child both at home and at the center differ from those avallable in the United States in their

54wagner, "Group Care," op. cit., p. 10. 
particular emphasis on the development of creative imagination and fantasy. Toys of predetermined use are avoided as being detrimental to the development of creativity. Scrap wood, cartons, and other refuse material are widely utilized as craft and play mediums. A1though with the rising standard of living in Denmark many Danish children are given more toys, there exists a tendency toward a belief in spurring a child's imagination through avoiding the imposition of structured play by use of functionally open-ended toys. Children are encouraged to bring a toy or some item from home to the center to help ease the transition from home to center.

Individual differences in children are taken into consideration to the maximum extent possible. Although all infants may have their solid feeding at about the same time or nap around the same general period, the infant who needs the most rest is put down first and taken up last. Milk feeding is on demand and the infant is always held for the feeding. Food for infants is prepared by a cook at the center, and the formula for each night's feeding is given to the parents when the child is picked up.

One may note, at this point, the striking differences between the Danish vuggestrue and the cretch in Soviet Bloc countries, another model for large-scale group care. In Czechoslovakta, for example, development is stressed along predetermined lines of normal development. The Danish form of care stresses individual freedom 
to develop along the chlld's own lines, as indicated in individualized feedings. 55

Infants throughout Denmark take their naps out of doors under a covered area in all types of weather. Where this is impossible, the child sleeps in a room with all of the windows open. They sleep most often in their perambulators (perambulators appear to be far more prevalent than in the United States) or special cribs under down-filled comforters. The Danes untversally agree that this practice builds the infant's resistance to disease, particularly colds, and promotes sound sleep.

The vuggestrue is not a universally accepted form of care in Denmark at this time and is, more often than for care of older children, chosen out of necessity rather than for its benefits to the child. Many of the questions about such care which plague Americans are st111 raised in Denmark. A primary question is whether day care programs for infants interfere with the attachment needs for a mothering figure of the infant at a critical developmental period so as to affect a later incapacity for close relationships or, more specifically, will the vuggestrue interfere with the attachment to the natural parents. 56 ;

55 Marsden Wagner and Mary Wagner, "Day Care in Denmark and Czechos lovakia" in Resources for Decisionmaking in Day Care, (Washington, Office of Child Development, 1970), p. 34.

56 Ruth Iverson, "Impressions of Differences Between Danish and American Child Rearing and Child Psychology," (unpublished, 1959). 
A family day care supervisor noted that the continued popularity of family day care may, in part, be explained by this same general question in the minds of many parents. To offset this, the staff of the vuggestruen were, until approximately five years ago, directed to wear white uniforms resembling nurses' uniforms and encouraged not to touch the infants or do anything which would cause them to compete with the natural mother for the child's attention. This practice was abandoned with the recognition of the phenomenon of "hospitalism," which appeared to occur in similarly sterile situations. 57 Currently, a staff member will take primary responsibility for two or three infants and will almost endlessly have one of those infants in arm, playing and talking. An emphasis is put on a maximum of interaction with both staff and, when appropriate, with peers. Although a child may interact with several adults and children, he has the opportunity to return to a single, stable, adult figure.

For the purposes of this study, the question remains unanswered as to how the close contact of the infant with a surrogate mother affects his attitude toward the natural parents. The Danes appear convinced that this type of care is not only acceptable but desirable in many cases. They feel that the pressures from which the family is relieved by the avallabllity of such care are, in themselves, beneficial. They note that often a child is able to bulld a closer

57 Rene Spitz, "Hospitalism: An inquiry into the genesis of psychiatric conditions in early childhood," Psychoanalytic Studies of the Child, I, pp. 53-74. 
relationship with the mother due to the fact that she spends less actual time with the child and, hence, values that time more and carries a more positive attitude toward their relationship.

In the toddlers room, the scene is somewhat different. As the children master walking skills, they are presented with more large motor coordination activities. Tricycles and hobby horses appear. Snacks and lunch are eaten at tables with attached chalrs. Toddlers, under close staff supervision, begin to feed themselves. They now take naps on cots which fold out from the wall and are replaced during play time to provide floor space. The lunch hour that the authors observed in the toddlers room left us pleasantly surprised. The noise level was low. Each child sat in his seat, and the adults sat near the children's table. Conversation took place before the meal arrived. The staff served the fool, and each child willingly ate with silverware. When the meal was finished, the children sat at the table for a few more minutes, and then without reminders from the staff, went into the bathroom area and prepared for naps. (Undressing, brushing teeth, and tolleting.) Most centers observed provided some sort of soft toy for the children to nap with. Those children unable to sleep are allowed to play quietly with their toy. In the oldest subgroup, equipment is again planned with a great deal of awareness of child development. The chairs are not attached to tables for eating. Arts and crafts activities become increasingly available at this point. They seem to hang from everywhere. Materials 
for activities are stored primarily on open shelves, where they are easily accessible to the children. The chlldren themselves are given virtual free rein to move about the factlity, including out of doors, at will.

It is during this period that the largest number of children are learning tollet training. Tollet training is undertaken in line with cultural attitudes which indicate that one must wait until a child is "ready" to understand the meaning of tollet training. 58 This is presumed to occur at about age two, when the child can walk and talk. There is little direct pressure put on the child. It was said that the few children who do not catch on, do so as soon as they enter a center for preschoolers, where every child is tollet trained, and they can observe others and be assisted by staff; e.g., naptime. Hence, toilet training is not a particularly emotionally-charged issuesbut rather one which is viewed with a large amount of tolerance and patience, with the understanding that the child will become tollet trained but only when ready. Tollet training was never mentioned by staff as a problem.

Children are taken out for walks almost daily in groups of anywhere from two to ten children. Emphasis here is put on famflarizing the child with his neighborhood, the people who live in $1 t$, and the activities which take place there. Staff members rarely leave the center to purchase supplies without taking some ${ }^{58}$ Iverson, op. cit., p. 4. 
children along. On any given day, in any given neighborhood, one may observe groups of vuggestrue chlldren out for a walk or ride in their perambulators.

In the initial phases of the development of current vuggestruen programs, it was belleved that the staff responsible for the care of infants were in need of less training than those caring for older children. In line with this, they were given a one-year training program (deemed useless by several vuggestruen directors), where staff working with older children were given three years' training. It was, in fact, realized by the Ministry of Soctal Affairs that those caring for infants were in need of more training than the others. Vuggestruen staff currently being educated are thus enrolled in a three-year program. (See chapter on the Seminarium.)

of significant interest to the child care workers we spoke with, both in this program and the preschool program, was the length of the child's day at the center. Child caring staff at several centers spontaneously volunteered that nine to ten hours per day in group care seemed to be too long for children of this age. The problem is compounded by a few mothers who bring their children in as early as possible and pick them up as late as possible to maximize the amount of time they do not have to cope with their children. There are half-day programs at most centers for chlldren whose mothers may not work. This program is encouraged by those who see this to be the ideal amount of time, from a developmental standpoint, to spend 
in group care. It was sald the state is currently giving consideration to shorter work days for women with smalli chlldren (approximately six hours) with equal pay.

\section{FAMILY DAY CARE}

Current professional attitudes toward family day care as opposed to group care in Denmark view such care as essentially regressive. Primarlly, it is felt that child care should be left to trained personne 1; however, seven years ago, the Copenhăgen Kommune began to look to family day care (dagpleje) to meet the huge demand for child day care".

Although private, unsubsidized family day care is legal (with the approval of the state) in Denmark, most non-relative family day care appears to be arranged through kommune-operated and subsidized programs, pioneered in the Copenhagen Kommune. There are substantial financial benefits for both the provider and the user, plus an array of quality assurances through heavy supervision. Family day care not carried out through the kommune-operated family day care system is often carried out illegally in order to recelve added, unreported income without losing housing subsidies received by many families, or paying a heavy income tax.

Prior to 1964, the family day care program consisted solely of an inspection of the family day care provider's:home. In. 1961, there were 688 children in licensed homes in Denmark. In 1966, the Copen- 
hagen Kommune established the first formal, government-sponsored system of family day care in Denmark. By 1972, 170 of the 250 kommunes in Denmark had established family day care programs caring for 14,000 children. A great number of these programs were established in rural areas where group care often required traveling long distances to reach a center, 59

In addition to the aforementioned reasons for family day care, other advantages to families were expressed by child care staff and administrators. Although probably to a lesser extent than in the United States (due to the long-standing program of group care on a large scale in Denmark), many famtlies prefer family day care to group care for personal reasons. They may wish their child to be with only one surrogate mother or value the more personal relationship both they and their child can have with a provider responsible for the care of only a few children. Of prime consideration in the establishment of family day care programs was the removal of the financial transaction between the parent and provider. As in group care, there is a feeling that financial considerations can only serve to impede the relationship of the parents and provider and lower the quality of care. Finally, the importance of the security and assurances provided by a supervised system of care was expressed.

${ }^{59}$ Marsden Wagner and Mary Wagner, "Family Day Care in Denmark," (Washington, Office of Child Development), $p, 1$. 
Family day care through such supervised programs is only avallable until the age of three in the Copenhagen Kommune. At that age it is felt that the establishment of relationships with peers is important enough that group care is indicated for the promotion of sound development. As with group care, the walting list for family day care is long. In Copenhagen, 750 children are in placement and 600 more are on the waiting 1ist. Mothers anticipating the need for care may sign up as soon as they find they are pregnant and call back each month to reconfirm the need for care. The Ministry of Social Affairs' current attitude is that the type of day care selected should not be affected by a family's abllity to pay, hence the cost of family day care to the parents is scaled so as to be approximately equivalent to the cost of group care and is determined by a sliding scale of fees according to the parents' income. All financial transactions are made through the family day care office and never between parent and provider.

It is felt in Denmark that there is a certain group of children for whom family day care is clearly superior to group care. These are chlldren under the age of three who are considered to be at high risk from a developmental standpoint. 60 These children, generally referred to the programs by physicians, soctal workers, public health nurses, parents, and others, are frequently babies of unwed mothers, broken homes, or homes with some known pathology

60 Ibid., p. 1. 
(homes with retarded or disturbed siblings or an alcoholic parent are examples). Children of student-parents, of low-income families, or children with chronic illnesses may also be included in this group. Whereas the waiting list for family day care is long, these highrisk children are given first priority and generally are not forced to wait.

Children with physical handicaps and behavior problems are also considered to fare better in family day care. All exceptional children are placed only in specially identified homes capable of caring for the child. In Copenhagen, 100 out of 600 homes are approved for the care of the high-risk child. Providers in these homes frequently have had previous training and experience in child care. They are often former group care workers. Regrettably, the Danes have no data to substantiate their belief that family day care is superior for the care of high-risk children.

Recruitment of family day care providers is achieved through radio, television, notices in public areas, and, to a great extent, through word of mouth. Potential providers who contact the family day care office are given a brochure describing the program and an address card to complete. Before any further action is taken, health and police records are screened. If all is well, an interview is scheduled in the provider's home. The home is inspected for size and cleanliness, but primary emphasis is put on the attitude of the provider. In considering the situation, the primary question becomes: Will this home be appropriate as a placement for one chlld 
on the waiting list? It is readily acknowledged that what is appropriate for one child may not be for another. To emphasize the point, we were taken to the apartment of a provider located in the center of Copenhagen's "red light" district. On arrival, the door was open; there were both chlldren and adults parading through the apartment. The provider herself was physically huge and radiated tremendous warmth. It was said that her apartment was always like "the central train station" and inevitably in disarray. The provider cared for, among others, the chlldren of prostitutes who left their children before going out to work. No children had ever been referred to this provider by the program; she provided all her own referrals. Those who did receive care from her were pleased with the chaotic type of care she was able to provide. It is acknowledged that the ideal day care setting is not the same for all children and parents. Any inspection of a home is'made with all 700 chlldren on the wafting list in mind, al though the provider may seek approval of her home and work out her own arrangements with families. Socioeconomic considerations weigh heavily not only in the inspection but in the final matching of children and parents with providers. The matching of child to provider is done by the dagpleje worker (supervisor) in charge of the specific area. The parent and provider, however, have final say on the matching.

The family day care program also maintains an open att1tude toward innovative forms of family day care. Arrangements have been approved in which both a husband and wife were certified for the 
care of children. Of particular benefit in this type of arrangement is the presence of a male role modeling figure. Every effort is made to place children whose fathers are absent either in this type of an arrangement or one in which the husband of the provider is home during the day. A second innovative arrangements, the "mini-viggestrue," Involves a group of parents who band together and find one or two providers who work in the home of one of the parents. These two types of family day care arrangements have proved quite successful, and both parents and providers are encouraged to both extend their use and discover new types of arrangements.

Once the inspection of the potential provider's home is complete and information concerning the provider is compiled, it is submitted to a central office, together with a recommendation for approval or disapproval, for confirmation. Should a potential provider be disapproved, the applicant is told that there are no appropriate : children for placement in her area, rather than telling the potential provider that she is inappropriate. Perhaps this is dishonest, but it is also easier for the supervisor and easier for the potential provider to accept. Approval is initially made for only a thirteenweek period, during which the provider is closely supervised and evaluated. There are no spectal educational requirements for selection. Women chosen are generally between twenty-one and fifty-five years of age. Experience with this program indicates that this age range yields providers with both sufficient maturity and sheer physical strength to cope with infant care. Preference is given to 
women with experience in raising their own children. The providers are given a thorough physical examination and must have a yearly test for tuberculosis.

The family day care mother receives 160 Kroner (approximately \$28) per week for each child in care. of this amount, one-third is constdered to cover the added expenses for food andinctdental costs of caring for a child and is tax exempt. The program supplies the providers with such items as diapers, perambulators, "and toys and will, whe re considered necessary, subsidize the cost of improvements to the home necessitated by the child, such as installing grating over exposed windows.

The providers must be available from six a.m. to six p.m. but should not work for more than nine consecutive hours. The provider is paid regardless of whether the child is actually in care or at home due to illness or vacation. This is considered to be a situation which is not under the control of the provider, since she is actually "avallable for work.

The number of children for which a provider may care is stipulated in the contract with the family day care program. The legal $11 \mathrm{mit}$ is seven (which includes the provider's own children of preschool age), For all practical purposes, the limit is four children: The most common contract $11 \mathrm{ml}$ tation is three, and most providers care for only two children.

In the past two years, the family day care providers have organized a union: which works closely with the union of group day care 
workers. The focus of inttial negotiations concerned increases in vacation benefits (raised from 9.2 to 10 percent of the gross eamings). Current negotiations on the second contract are almed at gaining regular cost of living adjustments in salaries.

The family day care supervisors appear to be the essential element in the success of the famlly day care program. There are ten supervisors in the Copenhagen Kommune program, each supervising a caseload of thirty-five to forty homes. The supervisors may come from a variety of back-rounds, but the most common one is that of a child care worker in a vugges true.

While currently the supervisors work from a central office in Copenhagen, plans are underway to locate the supervisors in local offices in the districts they serve. The supervisors are avallable at the office from eight to nine each morning to take calls from both providers and parents. Much of the remainder of the day is spent visiting the providers' homes. Should a day care mother become $i l 1$ or otherwise unable to care for the children assigned to her, she may call in before nine o'clock, and a substitute provider 1s located. Substitutes are drawn from either providers whose assigned children are $i 11$ or on vacation or from providers approved for more children than they actually have in care.

Should a child become 111 , the parents may call the supervisor and, if necessary, a homemaker service is arranged. Should a child become ill during the day, the provider is instructed to immedlately 
call the child's mother to discuss the situation. In fact, due to the generally close relationship between parents and providers, the child may stay at the provider's home in spite of most 11 inesses.

The inftial meeting of the day care provider and the parents and child to be placed occurs at the provider's home with the family day care supervisor present. When the appointment is made, the parents of the chlld are told the block in which the provider lives but not the house. This is done to insure that the parents will not meet the provider until the supervisor is there to introduce them. The meeting generally begins with the supervisor's explanation of the situations of both the family and the provider and an explanation of program policy and procedure. The discusston then turns to a familiarization process and questioning of the supervisor. The supervisor then leaves to allow the two parties to further acquaint themselves. Should either party be dissatisfled with the arrangement, they are encouraged to contact the supervisor, and new arrangements are made. Initial screening and supervision of the contacts make dissatisfaction at this point rare.

The day care provider makes a "surprise" visit to each provider's home twice a month. This requirement is made explicit to the providers from the start and, hence, few providers are unsettled by these visits. In accompanying one supervisor on approximately ten "surprise" visits, it was found that we were warmly recelved in every home. The visit almost invarlably took on the alr of a soctal occasion. The providers appeared particularly anxious to "show off" 
their children to foreign visitors. The rapport between this particular supervisor and the providers in her caseload was close. The supervisor's primary function in these visits appeared to be a provider of moral support and advice in coping with a broad range of problems not necessarily associated with the provision of care.

The family day care program is not solely a service to the families and children served, but is also a service to the providers who are given the opportunity to exercise and be paid for special skills in child care without being called upon to work outside of the home. The majority of the family day care providers may be grouped into three basic types, according to their reasons for entering the field. The first type of provider has infants of her own and feels that the care of extra children would require only a small amount of extra exertion. The second type of mother has children of her own in school. She wants extra money of her own but wants to be at home, available to her own children, and does not want a full eight-hour day in an office or factory. The final type of provider is the older mother whose children are grown and desires substitute children. In practice, no one type of motivation may characterize a superior provider. Most providers are motivated by a combination of the above circumstances.

Although there is no special training given to day care providers prior to starting in such a career, there is a program of inservice training. In smaller kommunes, this may consist of day care providers meeting with their supervisors once a month. In the 
Copenhagen Kommune, the program has been formalized into the evening school system. A sixty-nine-hour course for day care providers has been developed. The providers attend the class one night a week for three hours over the course of five months. Different authorities cover subjects which include legal responsibilities and child law, child health, nutrition, first aid, growth and development, creative play, and parent interaction. 61

Another recent innovation in the inservice training program for day care mothers is the holiday camp. The kommune sponsors and arranges for a group of day care providers to spend: a week in the country with their own preschool chlldren and their day care children. Five or six day care providers, with twelve to fifteen children, stay together with their supervisor, a group child care worker, and two assistants. During the day, the child care worker and her assistants care for the children while the day care providers and the supervisor see educational films, have discussions, and relax. The camp provides the opportunity for the supervisor to intensively observe the day care provider and the children.

Having briefly discussed the structure of the kommune-operated family day care program, we will summarize both advantages and liabilities of such a system.

Advantages include:

1. The close approximation of a normal home environment in the

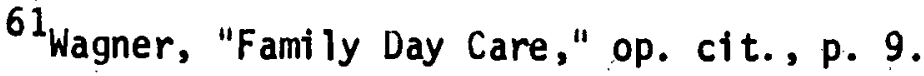


family day care home. This is particularly relevant to children whose own home environment is lacking; e.g., in superviston and care. 2. A smaller likelthood of contracting communicable diseases. 3. The opportunity for children of fatherless homes to observe and interact with a paternal figure in the provider's family. 4. The close contact between parents and providers. Parents are given the opportunity to learn from the experienced day care provider. 5. Greater flexibility in chlld care should an emergency arise. For example, the child may stay overnight in the provider's home should the necessity arise.

6. A family day care home system can expand exceedingly fast without large expenditures for new factlities, utilizing a reservoir of caretakers already in existence.

7. The provistion of care for parents who prefer family cace or children who may be expected to benefit from family care as opposed to group care for physical, social, or emotional reasons. In these cases there is some measure of assurance of quality care. Llabilities include:

1. The greater $11 \mathrm{kelihood}$ of moving a child from one home to another, particularly when the provider is working on an initial thirteenweek contract. This occurs in spite of close inspection of the homes, ongoing supervision, subsidized wages, and careful matching of the provider and child. 
2. Family day care cannot provide the flexibility of staff within the setting possible, within the group care setting.

3. Family day care entails a lesser degree of certainty regarding the quality of care provided. Providers are not trained to the extent that group workers are.

4. Physical facilities, in spite of the program's supply of equipment for the provider, are not as extensive as in the group. care center.

5. The child in family day care tends to have less contact with peers, especially in a situation in which the provider has no preschool children of her own. 62 .

Clearly, more data will be necessary to fully evaluate the effectiveness of government-sponsored family day care programs, particularly in regard to the care of high-risk children. of particular note, however, is that a system of family day care with government subsidy and supervision has been established and is functioning reasonably effectively on a large scale. Parents, children, providers, and supervisors all express their satisfaction and fundamental belief in the concepts of the program. If for no other reason than the great demand for family care, it is clear that such an operation has a valid place in the Dantsh system of child care. :

${ }^{62}$ Ibid., p. 12 


\section{THE BORNEHAVE}

As noted previously, the vast majority of care given to threeto seven-year-old children is carried out in the group center. It is felt that the three-year-old child is beginning to develop social contacts with peers outside the family at this age. The b $\$$ mehave (referred to previously in this paper and in other works as the "kindergarten" or "preschool center") is far more common in urban than rural areas. Approximately 25 percent of all children in the three- to seven-year age range are cared for in the bornehavn (plura1), but in metropolitan Copenhagen, the percentage is more than double the national figure. 63

Bornehavn are, like the vuggestruen, open from six a.m. until six p.m. As more children in the bornehave have non-working mothers, most programs have children who attend on a half-day basis. None of the institutions discussed in this paper are part of the Danish educational system (they are under the Ministry of Social Affairs rather than the Ministry. of Education) and, seemingly to emphasize the point, are rarely located adjacent to public schools. Particularly at the b $\phi$ mehave level, child care workers emphasize that they are in no way a "school." Day care is a social institution, not educational. At times, we would mistakenly refer to the groups of children as "classes," which caused the child care

\section{${ }^{63}$ Statistik Arbog, op. cit.}


workers to remind us that they were not a school and, therefore, did not have classes.

The vuggestrue and b\&rnehave are frequently located adjacent to one another and are of similar design. Like the vuggestrue, the bomehave is divided into suites of rooms, but each suite is designed to accommodate a maximum of twenty children rather than ten or twelve. Mandated child-to-staff ratios in the bornehave is ten to one. ${ }^{64}$ Observations for this study indicated that a group of twenty children at this age level are supervised by one fully-trained child care worker, one untrained worker, and one student assigned to the center on a full-time basis as part of the practical experience component of his education.

Unlike the vuggesture, the groups of children in the bornehave are rarely divided according to age, and activities in the bфmehave differ greatly from those in the vuggestrue. Especially during the summer, when the weather is good and the children can play out of doors, much of the day is spent in free play. Group activities (directed and undirected) include singing games, circle games, painting and crafts projects, story reading, and reading readiness activities. Particular attention is paid both to the development of vocabulary and encouragement of fantasy play.

Where trips for the children in the vuggestruen are primarily oriented to the immediate neighborhood, the older children in the ${ }^{64}$ Wagner, "Group Care," op. cit. 
b $\$$ mehave are taken into the larger comunity to visit. industry, the countryside, etc. Each year the children are given the opportunity to spend a week at sumer camp as a group with their child care staff.

Routines vary widely from center to center, but generally the only fixed activities during the day are meals and, in some cases, naps. In most centers, children are given a choice as to whether they would like to nap, but no attractive activities go on during the nap time so that children will not be drawn away from naps by activity. After lunch one afternoon, we observed child care workers respond to requests for certain records to be played, and also certain games to be gotten off shelves. Much equipment was provided ( $I$ believe some of it for our benefit), and children were free to pick an activity, or go into another room, or do nothing. Schedules are almost unknown in Danish day care. At one center, a schedule had been established, only to be abandoned shortly thereafter as unmanageable and restrictive.

\section{PROGRAMS FOR SCHOOL AGE CHILDREN}

Al though the primary focus of this work is on programs for the care of preschool children, one must realize that the vuggestrue, dagpleje (family day care), and bqmehave programs comprise only a part of the total program of non-residential care for children. Because of this, techniques developed for the care of school age children have been uttlized in the care of younger children and vice 
versa. All of the programs are carried out under the auspices of the Ministry of Soctal Affairs and share a great number of common aspects.

After school programs for children ages seven to fourteen are divided into two main groups: the recreation center (fritidshjem) and the recreation club (fritidsklubber). The recreation center is, to a larger extent than the bqmehave, intended for children from socially and educationally disadvantaged home conditions, such as the case in which the mother is often employed, and the home, often too small, offers poor opportuntties for children's activities. Denmark has been plagued by a housing shortage since the end of World War II, and living quarters are, in major cities, generally apartments too small to allow for free play. In addition, one must take into account the long winters, increasing traffic, urban streets, and public squares which are becoming progressively less suitable as playgrounds for children.

Recreation centers have facilities for occupying children in various sorts of work and play. Each after school group has about twenty children assigned to one director. They have a "homeroom" which serves as a free play room and which they may decorate as they wish. They are allowed free run of the facilities. They may choose among a number of crafts; a woodworking room, metal

$$
{ }^{65} \text { Toft, op. cit., p. } 30 .
$$


shop, ceramics, and painting, each staffed by a specialist who may be a practicing craftsman employed by the center on a parttime basis. Recreation rooms include ping pong and pool tables, other table games and chairs for lounging, and a snack bar. Kitchen facilities are avallable for those so inclined. There is a library room where children can study, read, or simply be alone. No child is coerced into studying, but staff are available for tutoring by request. In centers adjacent to vuggestruen and bornehavn, the older children may visit or assist with the younger children, 66

Since virtually all Danish primary schools are run on staggered or double sessions, the recreation center is open for a full day, caring for children both before and after school. The children are required to check in and out, generally with the director, and a chart shows their school schedule so that, should a child not show up at the center when not in school, action can be taken to locate him. Recreation centers carry the responsibility of accounting for the whereabouts of the child during the period that his parents are working. Eighty percent of the children in recreation centers are under the age of eleven years. 01der children prefer the freer form of care in the recreation club. ${ }^{67}$

$$
\begin{aligned}
& { }^{66} \text { Toft, op. cit., p. } 28 . \\
& { }^{67} \text { Ibid, , p. } 30 .
\end{aligned}
$$


Recreation clubs do not require the child to check in or out. They may come and go as they please. These clubs are generally run in conjunction with a youth club for older adolescents and normally have a larger variety of occupational factlities.

Recreation centers and clubs are staffed by trained workers who have undergone education along the same lines as the vuggestruen and bornehavn staff, but in separate schools which emphasize work with older children.

Included in the classification of youth clubs is the scramelespladen, a term which is often translated into "adventure playground." The literal translation, "junk playground," seems to come closer to capturing the spirit of the scrammelespladen. It $1 \mathrm{~s}$, to the greatest extent, constructed and controlled by the children. Buildings designed and constructed with the help of engineers, architects, and craftsmen are made largely with surplus and scrap material from construction sites. The children determine what kinds of facilities they want and participate in both the design and construction. The result is that the scrammelespladen consists of one main rustic bullding housing the office, kitchen and crafts rooms, and animals. The remainder of the construction consists of small shacks used like clubhouses, a campfire area, large ships and rockets, towers, recreations of ancient Nordic huts, and anything else that the children fantasize.

The center observed is open from seven a.m. to eight p.m. and is used by 150 children, supervised by a staff of ten. The 
children range in age from seven to eighteen years. They pay a 12 Kroner $(\$ 2.10)$ Initiation fee and 10 kroner per month. The club recelves almost the total non-governmentally subsidized portion of 1 ts operating budget from the developer of the apartment complex adjacent to the scramelespladen. Government subsidy for scrammelespladen is identical to that of the recreation club. Animals often play a large role in the scrammelespladen. The center visited included several horses, goats, pigs, chickens, ducks, and rabbits. Many of the an 1 mals had free run of the grounds. Al though children were expected to take full care of the animals, a full-time staff member was assigned to assure their care when the children were negligent. Children were allowed to "buy" a rabbit for a small fee plus a nominal monthly amount to cover the cost of the food. They are responstble for the care and feeding of the animal. Recently, the community had been outraged when $1 t$ was discovered that the animals sometimes went for long periods without care should a child lose interest. Notwithstanding, the children do share in a great deal of the upkeep of both the animals and the factlity.

This is one of twelve such playgrounds in Denmark; however, the concept of allowing children to butld villages out of scrap materials has been integrated into the programs of many day care centers. Indeed, virtually all centers make extensive use of all forms of scrap materials for numerous activities. 


\section{THE INTEGRATED INSTITUTION}

Among the most recent innovative concepts in Danish day care is the "integrated" institution, in which children of all ages are cared for in mixed "family" groups in a single institution. Observations and interviews were taken from one of only four such "integrated" centers in Denmark. The center observed had become integrated not so much by philosophical bias as by the architecture of the existing factlity. The center itself is located in a suburb of Copenhagen. The butlding is approximately five years old but differs radically from the Ki Ta Dan system of prefabricated architecture. The basic structure is that of a huge central room with suttes of rooms around the periphery. The central room is awesome, approximately one hundred fifty feet square with a thirty- to forty-foot-high celling. The effect is that of enabling outdoor types of play indoors during the winter. In order to justify the expense of such a structure, it was necessary to design the facility to accommodate approximately one hundred fifty children. Initially, the program had established separate programs for different age groups within the same building; the children themselves began to mingle.

The program was integrated during a gradual process. The only children excluded from the integration process were the infants too young to walk. It was felt that these infants demanded specialized facilities that could not be provided for each group. 
Nevertheless, older children have shown a good deal of interest in the infants and spend a considerable amount of time caring for them.

The remainder of the rooms include toddlers to age fourteen. The purpose is to recreate the family unit. older children model behavior to younger ones and, in turn, learn from the experience. Each room has approximately twenty children, including a few halfday children and older children in either before- or after-school care, so that the rooms will have approximately fifteen children present at any one time.

Caring for such a wide range of children presents some problems. Few activities at the integrated center include all ages at one time, but few activities in any day care center in Denmark involve the entire group. 0lder children can be drawn into younger children's activities as supervisors, while younger children can observe what the older children are able to do in their own activities.

This particular center is blessed with a weal th of resource areas for activities. One full-time staff member is assigned to the scrammelespladen area. Another is in charge of a dramatics area, where the children may dress in costumes for fantasy play, give stage plays, or puppet shows. There is an auditorium capable of seating the entire center's population for shows given by theater arts and music students from the University of Copenhagen. There is a tremendous terraced flower garden. 
80

Outdoor play areas are divided into three basic sections.

One of these sections is oriented to the play of the infants.

Equipment includes a number of large climbing structures. One.

slide is capable of seating five children at once and sending them into a sandbox approximately. twenty-five feet square. 


\section{CHAPTER IX}

THE PAEDIGOGUES AND THE PROGRAM

It became apparent after observing only a few centers that the answer to success of the program of group day care in Denmark lay, to a large extent, in the quality of the chlld care workers. Denmark produces 600 fully-trained chlld care workers (paedigogues) yearly from fourteen schools, each spectalizing in ef ther work with infant, preschools, or older children. Much to their dismay, the paedigogues' status is not equivalent to that of teachers, who are university graduates. However, paedigogues are the acknowledged experts in their field, so much so that they tend to ignore the parents of their children, as will be discussed later.

Untrained chlld care workers recelve about 3,500 Kroner per month (about \$615). Seminarium-trained paedigogues receive only about 10 percent more, 3,800 Kroner $(\$ 667)$, raised to 4,000 Kroner $(\$ 702)$ per month after two years of experience. The incentive to education rests not so much in the additional salary, which is only slightly higher, as it does in the feeling that training represents a commitment to a career in child care.

The Danish centers make extensive use of volunteers and trainees assigned to work at a center as part of their practical experience. Many of the volunteers are military conscientious objectors working in the center as an altemative to military 
service. They are paid by the military. One center had been located immediately adjacent to an apartment complex for senior citizens, hoping to draw the senior citizens into the program of the center. The plan was abandoned when it was found that the senior citizens couldn't tolerate the noise and activity of the child care center.

The paedigogues are supported by staffs of consulting psychiatrists and psychologists. These consultants are used only sparingly, as the paedigogues are both confident and competent; thus, problems are generally handled within the center.

An inspector from the Department of Welfare Services noted that the paedigogues tend to follow a more leftist socio-political orientation than the families they serve and that this has created a schism between the two parties. The paedigogues are being encouraged to write down their program and philosophy in a form that can be understood by the parents. Too often, it was sald, the paedigogues expect parents not to question the logic behind practices they disagree with. This situation is representative of a larger division between working class conservatism and professional 1 tberalism concerning chlld care practices in Denmark. 68

An example of this rift occurs in the use of pacifiers. They are readily avallable, even to older children, as a means of allowing for temporary regression. Parents are angered by this; ${ }^{68}$ Iverson, op. cit., p. 2. 
al lowing pacifiers is threatening to many parents who believe it is indicative of slow development or retardation.

With the children, the paedigogues are relaxed and comfortable. They are able to engage the chlldren in play without any outward sign of self-consciousness. It is apparent that this attitude is only part of a larger community attitude of concern with children and appreciative of the childhood experience. Childhood is not rushed; in fact, it is, in many ways, prolonged. This is not contradictory to the pacifier issue. Prolonged childhood speaks more about kinds of responsibilities than particular behaviors. Physical contact with the children is encouraged in the b will generally also be in physical contact with the child. Nurturance is so much a part of the day care program that one is led to question whether or not the Danes reward dependent behavior on the part of children. Yet, when child care workers were questioned concerning the traits they would like to encourage in chlldren, they almost invariably cited "Independence." It rapidly became evident that this term had different connotations in this culture. When asked to explain what was meant by "independence," the paedigogues spoke primarily in terms of freedom of thought and action, rather than as not being physically dependent on others for support. American children are physically self-supporting and independent at an earlier age than Danish children. 69

${ }^{69}$ Ibid., p. 10. 
Behavior modification techniques were discussed at several of the centers. Few paedigogues were initially aware of the technique. Those who were, were repulsed by the idea and questioned why one would consider it advisable to alter a child's behavior in any but the most drastic of situations. They acknowledged its probable effectiveness but stated that they felt it was not the prerogative of a child care worker to "mold" a child.

The Montessori movement was strong in Denmark in the early twentieth century but lost favor. Several paedigogues stated that they were currently reintroducing Montessori methods, but only as a part of the larger program. It was said that a totally Montessori program was too rigid and did not allow the child enough freedom to explore the world as he pleases.

Mealtimes became one focal point of observation. It was noted that at each center observed, meals were orderly, fairly unchaotic affairs. Adults would sit at one end of the table and children at the other. There was no need for adult supervision of the children's activity. Both groups carried on separate conversations. Children took part in both serving and cleaning up after the meal without encouragement. Danish children did not appear to be meek or particularly compliant in other situations. One is able to understand the situation only by citing a number of factors:

1. Meals serve a different function in the Danish culture. They are drawn out to great lengths and are looked upon as an occasion 
for family interaction, in which the child is expected to participate.

2. Meals served at the center are exceedingly simple and easy for the children to eat. They usually consist of a single dish. It is acknowledged that meals may not always be nutritionally balanced. Until Denmark's recent entry in to the European Common Market, fresh fruits and vegetables were not readily available In Denmark at reasonable cost for long periods of the year. To augment these meals, the children are given vitamin supplements. 3. There are a large number of staff at mealtime to handle problems that do arise. The staff also serve as role models.

4. The staff allows a good deal of noise in retum for cooperative behavior in other areas.

Denmark has become famous for its sexual permissiveness in recent years. Nudity at the child care center is fairly common even among older children and is considered beneficial to the development of healthy sexual attitudes.

The staff of each center contacted greeted our visit regardless of whether or not is was announced. At no center were we turned away. Most centers were eager to show their programs. At each center, interviews were conducted over coffee at a table near to where the children played. During the time spent in interviewing, the children made no attempts to disrupt. They came to the staff as problems arose and either left immediately or stayed and simply listened quietly. They demonstrated no 
jealousy over their loss of attention by the staff. As we moved away from the table following the interview, the children approached us freely. It was said that this behavior is expected of the children. Coffee breaks are considered to be examples of adult role modeling behavior.

During the time spent in observation at the centers, paedigogues appeared to see little need to supervise directly the activities of each child. Children in the bomehave may be allowed to hammer and saw wi thout supervision should they choose.

Certain phenomena were noted in centers that came as a surprise. In numerous centers, certain obvious dangers are allowed to persist, such as old cars or trucks with broken doors and windows. When the paedigogues were questioned regarding the presence of such dangers, they argued that children must learn to deal with dangers that are part of the child's environment. Biber claims similar atti tudes in saying, "It is not the intention of educators to spare the child the inevitable conflicts of growing; this, if it were true, would be the most egregious error of all, since it is through the meeting and resolution of conflict that the self gains and feels its deepest strength. " ${ }^{70}$ Although these are two similar themes, the ideas are vastly different. Biber speaks against staff intervention when the children has to deal with his own interpersonal problems. It appears that this attitude is

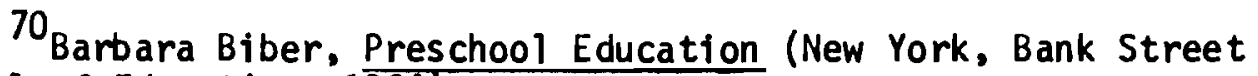
School of Education, 1964). 
a preliminary step in achieving the posture of the Danes in terms of a child's ability to deal with and resolve problems.

The child care worker in the United States is working to trust and allow a child to resolve problems in his private, personal world, as are the Danish paedigogues, but the paedigogues are also confident enough in the child to allow him to deal with certain physical dangers which are not present in many centers in the United States.

The staff at one private recreation club and bomehave may well have represented the logical extension of progressive thought in Danish day care. They characterized their program as one operating on the principles of A.S. Neill's Summerhill school. Staff stated that the children are allowed to do anything they please, providing it is not destructive and they are able to verbalize what they are doing. The center carried the arts and crafts phenomenon to its extreme. So cluttered was the center with projects of all sorts that even the staff admitted it was probably a fire hazard.

There is a noticeable lack of authoritarianism on the part of virtually all child care workers. Especially at such progressive types of centers as the scrammelespladen, it is difficult to distinguish the children from staff. Interaction between child care workers and children is warm and mutually respectable. The children and their ideas and desires are taken seriously in the implementation of the program. 
Corporal punishment is rare in Denmark and is replaced by frequent verbal warnings, even in working class families. 71 In child care centers, corporal punishment is virtually nonexistent and certainly frowned upon. There exists a basic belief that any child engaged in disruptive behavior can be talked out of it, given a sufficient amount of time and patience. In verbalization, we noticed that emphas is is placed on moral responsibility to others ("You don't want to hurt that other child. You would not like to be hurt, and net ther would he.".). Heavy emphasis is also placed on positive modeling behavior by adults and demonstration of acceptable forms of alternate behavior. At one vuggestrue, two toddlers in the sandbox were throwing sand and putting: it on each other and into their mouths. One paedigogue took a pail and a shovel and, with the two children watching, began to fill the pail and exhibit other appropriate sandbox bebaviors.

The sources of problem behavior are considered to be explicable in terms of family functioning. Conferences with parents and parental education sessions are used to deal with most problem behaviors wich persist even when discouraged at school.

An example of this situation was noted in the aggressive behavior of a child new to the center. In conferences with the child's mother, it was found that she had encouraged the boy to be

${ }^{71}$ Iverson, op. cit., p. 10. 
aggressive to protect himself. Conferences with the mother had brought her to the realization, through verbal acknowledgement, that she had taught the child to be both fearful and aggressive towards others. The staff belleved that further sessions would prove successful and, al though famtly gutdance workers could have been suggested to the mother, they were not considered necessary. It was evident from observations that a great deal of disruptive and destructive behavior that is actually attention seeking is limited by the avallability of a large number of staff. Attention-seeking problem behavior is unnecessary where the staff has time to respond to appropriate seeking of attention. Because of their accessibility, child care workers are also particularly. adept at handiing the withdrawn child. 


\section{CHAPTER $\bar{X}$}

\section{THE SEMINARIUM}

The training of paedigogues is very specific and is accompIfshed through a three-year course at a seminarium, simflar to a juntor college in the United States.

Twenty-seven seminariums now exist in copenhagen and its surrounding areas for the training of paedigogues for the age group of birth to seven years. The twenty-seventh opened last year. All of the schools follow an identical outline of course material to be taught and a breakdown of hours to be spent in each of the various training mediums. The seminariums all drew materials from the resources of a central library devoted exclusively to the subject of early childhood education. The manner in which the material is presented is decided separately by each seminarium, in conjunction with their philosophy. "This allows a great deal of individual difference between schools.

The overall system of seminariums is set up in a way that correlates directly with the categories of day care. A seminarium exists to educate staff towwork in the vuggestruen, børnehavn, and fritidshjem. Each level of day care has specific teacher. training. Thereits a different emphasis in each type of seminarium, "most obviously shown by the breakdown of hours enlisted in specific fields of study. Overlap between the seminariums does exist. 
The discussion in this chapter will relate to the bornehave seminarium. Indication $w 11 l$ be made if the information varies on the different levels of the seminarium.

There are now seventeen b $\phi$ rnehave seminariums, five fritidshjem seminarium, six seminariums which have intermingled both bogrnehave and fritidshjem programs, and ten vugges true seminariums.

The seminarium program for b $\phi$ mehave has recently been expanded from two to three years. One year (six months the first year, three months the second and third year) is spent in the classroom for practical training. The largest amounit of time (284 hours) is dedicated to the educational aspects of the paedigogue training. The law states that 263 hours are to be employed in various creative workshops (arts, crafts, and music); 193 hours in the fields of psychology and sociology; and movement, gymmastics, and Danish language 112 hours each. ${ }^{72}$ other areas which carry lesser time requirements are: dramatics, nature, soctal medicine, psychiatry, interview techniques, and ethics. The student is allowed 284 hours of electives. The qualifying exam is given at the end of the third year, in the last month. Students are not graded, per se, during their training, but rather informally rated.

${ }^{72}$ Mars den Wagner and Mary Wagner, "The Training of Group Day Care Workers in Denmark" (Washington, Office of Child Development), p. 4.

$$
{ }^{73} \text { Ibid., p. } 10 .
$$


An advanced seminarium exists to further train paedigogues. Usually people attend this seminarium in order to qualify for the position of director of a child care center, or to teach in a seminarium.

Earlier, the question of individuality was raised. It is difficult to imagine individuality when every school must follow stringent regulations. The way this issue is approached is by leaving the material to be taught, in general, to be decided on by both the student and professor. No set reading list exists. The $\mathrm{class}$ decides the books they want to read in required fields. An outgrowth of this approach is the absence of the study of one man, system, or idea. For instance, in the field of psychology, there are no limits as to which psychologist is, or is not, to be read. Resulting is a belief in blending. Very few systems are followed in their pure state; rather, ideas are borrowed from diverse sys tems and mixed together in to one.

The seminariums are government supported, allowing all students to attend free of charge. The students are given a combination scholarship and loan to attend school. This money is to help cover living expenses and books. 74

Two thousand five hundred paedigogues graduate annually. An average of 8,000 persons apply yearly for the 675 places. Only 17 percent of the student body is male, though efforts are being 74 Ibid., p. 2. 
made to recruit more men into the day care profession. Many conscientious objectors serve in day care facilities and are attracted to remaining in the field.

The beginnings of paedigogue training dates back to 1885 , when the Froebel Seminarlum began the concept of child care training. The growth in the number of seminariums and paedigogues trained was slight, until after the second world war. At this point in Danish history, the need for day care boomed, and with it the need for educated paedigogues.

The seminariums visited revealed very well-equipped and welldesigned buildings. Each seminarium runs three classes of twentyfive.

Classrooms are simflar to those in the United States; tables and chairs arranged in squares or circles. There are, however, numerous decorations, both informative and decorative.

Within the seminarium, arts, crafts, and music are heavily stressed. The arts are second only to education in the curriculum training hours. Crafts rooms have facilities for woodworking, leather work, metal, ceramics, oil, water, and finger paints, papier-mache, enameling, and many other mediums. Much creative theater work is done, and a performing arts room, consisting of stage, and auditorium, is generally part of the seminarium. Music includes the use of vocal and instrumental sounds, primitive and advanced instruments, and techniques as well. 
In one seminarium, a full-scale kitchen was provided for use by students in learning assorted recipes and cooking procedures, to later be included in their classroom experfence.

The aforementioned skills are all taught on an adult level. At the Froebel seminarium it was mentioned that the work is challenging when first taught. The challenge remains for the paedigogues to alter the process into simple steps for the children to follow.

The seminariums prepare the students well, in our opintion, for their chosen profession; however, other problems do exist. One basic problem relates to the paedigogues' desire for more time to spend with parents and outside group activities. In response to these desires, recently a strike was held. Underlying the need to strike was a primary need to improve the status of the paedigogues. They are low paid by virtue of the fact that the higher the grade taught, the higher the level of salary.

Other problems within the seminarium system relate to the overall conceptual setup. The Ministry of Social Affairs, supervisor of education for vuggestruen staff, is a separate part of the government from the Ministry of Education, supervisor of the training of both bormehave and fritidshjem paedigogues. The resulting problems deal with the separation and lack of communication between the two ministries. It appears that in the near future the two ministries will join forces to make a further integration 
of educational goals. ${ }^{75}$ A secondary $p l a n$ is now in the offing. It is to allow for mutual exchange of information between bornehave seminarium paedigogues and those paedigogues trained for elementary schools. A special class has been created (bqdmehaveclase) which prepares day care children, ages five to seven, for entrance into regular school. Teacher exchange of knowledge is possible. The class is held in a school and taught by bornehave paedigogues. At this point, it should be mentioned that a distinct weakness still remains within the program. There is an obvious lack of emphasis on the exceptional child. The only possible way to get an emphasis in this area is to find a group of similarly interested students and create special group projects.

Group work is done throughout the three-year period. The buildings usually have conference rooms for student groups to meet. The group process, therefore, influences much of what particular aspects of child care is to be taught.

The staff at the seminariums is composed of representatives from various fields. One director was a psychologist w1th great interest in the education of young children. He had written varlous children's books and was founder of the "little school" (private schools which enable extensive parental influence). He was also the founder of an international educational organization.

${ }^{75}$ Ibid. , p. 13. 
The director at another seminarium was trained in law and previously held a position involving legal rights of children. He also taught at the advanced seminarium.

At least one or two of the professors are paedigogues, who teach the practical classroom techniques. They may also function as field advisors, during the students' one year of classroom training. They have completed the one-year advanced training course.

There are usually members of the psychological profession:associated with the seminariums in a teaching capacity. A highly desirable staff person is someone well learned in the maze of social systems. Great emphasis is also placed on a working knowledge of the bureaucratic social services system. It is important for every paedigogue to be aware of the services offered by the state and kommune. Paedigogues should be aware of the basic maze: how best to get where one is going? The use of this information aids in factlitating a helpful and trusting relationship between parents and paedigogues.

There are faculty members skflled in the arts, crafts, and music areas; other backgrounds may be represented. The diversification of backgrounds help each seminarlum butld its individuality in educational approach and philosophical attitude. Individuality is of major importance to every school.

No concise statement can be made as to the type of person most desirable for training as a paedigogue. With a vast number of 
annual applicants, the process of choosing those to be admitted is difficult and massive. The applicants are in a highly competitive situation. Evaluation for acceptance is based secondarily on scholarship. Primary emphasis is on experience with children and general work experience. In the past, each seminarlum made the selection of their new students, but confusion forced a change. All applicants will now apply for admission to a central office coordinating all applications for admissions to the seminariums, avoiding applicants being accepted to more than one school, leaving unfilled positions.

A new emphasis is being considered: Educate the child as his parents see fit. Respect for parent wishes has been abused in the past. Raedigogues have been guilty of ignoring the parents, who may be intimidated by their supposed knowledge regarding the care of children.

One seminarium, in particular, is taking a strong stance against this type of attitude. Paedigogues are taught to deal with parents in a manner that exudes respect for the wishes of the parents. The emphasis is also on working closely with the parents and involving parents frequently in center activities. Paedigogues are taught the importance of parent meetings, and that the children are most benefited from consistency from adults they deal with frequently.

An accentuated theme is, "do not be misstonaries." This refers to the activist segment of the paedigogues. Generally 
speaking, paedigogues are considered radicals. An often-used addition to the original statement is, "not in your own center." Paedigogues are to be informal and natural when dealing with the parents and the community. The above-mentioned philosophy was expressed by one of the seminarium directors as that concept which would differentiate the graduates of his seminarium from untrained child care workers.

Child care workers in the United States are dealing with far more external pressures than are the Danish paedigogues. In the winter of 1972, for Instance, many United States centers were financially threatened. The child care workers were constantly questioning the security of their own positions. The extermal security afforded paedigogues allowed for comfort with in the center.

Seminarium training in Denmark guarantees the paedigogue a cholce of jobs. In the United States, no such guarantee exists. In a recent guideline for specification for Positions in Day Care Centers, the only qualification thought desirable for day care center staff was a bachelor's degree in early childhood education. Previous experience was not thought to be necessary. 76 Beyond the requirements is the fact that: the guidelines are not always followed. Many less credentialed persons hold staff positions, as well as persons from diverse backgrounds.

${ }^{76}$ U.S. Dept. of H.E.W., "Guide Speciflcations for Positions in Day Care" (Washington, 1965). 
The issue of the differences in the universities of the United States also arises. The program, approach, material, and emphases vary from school to school, further clouding the meaning of a degree in early childhood education. In Denmark, criteria for what is desirable in the paedigogue were decided upon and have been applied in the selection and education of the paedigogues.

Very few four-year schools in the United-States have programs to train staff in early childhood education. The curriculum that does cater to the preschool experience is usually found at the junior college level. For instance; a recent program developed at 0akland Community College ressembles, $1 \mathrm{n}$ some aspects, the Danish seminarium, with one major difference (and istrength) being the incorporation of parent and child development. The program is eighteen months long and trains parents whose chlldren are at the center in the areas of nutrition, health, and family counseling. The program works to involve parents closely with both child and mothers to attend school. while thier child is cared for:

The Bank Street School of Education in New York City has a program for training day care center staff. Instead of having potential'students apply to the school, a center contacts the Bank Street School and works out a training program for day care center personnel. Each member of the staff is, ideally, to be involved with the college in creating the program for the training process and what is to be taught. 
100

Perhaps the current movement toward technical schools and community colleges can create a more specific and standardized program for child care workers. Fie id placements and supervision seem to be a strong training technique.

Student individuality, which allows specific skills to be learned and built on various philosophical grounds, was very pleasing to the authors. 
CHAPTER XI

EDUCATION IN THE DAY CARE CENTER

After observing several day care centers over a perlod of one month, we met with a graduate student in early childhood education from Pennsyivania State University who was completing a study of education in Danish child care centers. She expressed her initial disappointment with Danish chlld care centers. We were shocked, as our impressions had been overwhelmingly positive.

The reason for her disappointment was that there is almost no programed educational component in most Danish centers. For many years, the Danes have talked about bringing education into the day care centers. This has not come about in such a way as to be readily identifiable in terms of education as it might be practiced in the United States. Most centers have a large number of educational games; however, they are often placed away in a cabinet and used only upon request. There is no formalized curriculum for systematic stimulation or skill training.

Achievement of educational benchmarks, such as the ability to read, are not among the foremost goals of the Danes, even in the public school system. The child who develops skills slowly is allowed to do so. Little, if any, pressure is placed on the chlld in the bornehave. The assumption is made that, as in toilet training, the child will read or use the tollet when he is ready to do so and not before. So alien to education is the bqmehave 
that the director of the most well-known (Froebels) seminarium opened a series of private "børmehaveskole;" which carry on the principles of the bprnehave in school. Students in the bofmehaveskole are able to move completely at their own pace,

What education does take place in the day care center takes place in the form of language development, which 15 carried out through large amounts of singing and storytelling. Emphasis is on spontaneous social development through a healty milleu.

Education at the preschool level is carried out in the kindergartenclase, a one-year program for children of ages five to seven, which is operated by the Ministry of Education. 


\section{CHAPTER XII}

PARENTS AND FAMILY IN DAY CARE

It is our opinion that there is a good deal of strength in the family structure in Denmark. This is in spite of a high divorce rate and a high number of unwed mothers. Much of this strength appears to be the result of concern with children and childhood, of which the system of child day care is only. a part.

Because of the high rate of taxation in Denmárk, many middleclass mothers choose to work. Their work is not necessary for the survival of the family but allows them to participate in a rising standard of living and correspondingly rising expectations in Denmark. New cars and summer cottages are two items which the Danes consider to be, if not necessary, at least highly desirable and worth the extra work which the wife is called upon to do. Added to this is the fact that industry encourages the voman to work in, this labor-short country.

At least as long ago as 1951, literatüre notes talk in Denmark of the need to include parents in programs for chilidren. It was found that, with isolated exceptions, parents do not and are not encouraged by day care staff to participate in the functioning of the center and its program. Exceptions to this trend were found in private centers, where active parents were found on the board of directors of the center. 
Interaction between parents and chlld caring staff in Denmark, as in the United States, occurs primarily, if not exclusively, In the periods during which the child is elther being readied to enter the center or readied to go home. The architecture of the centers is designed to encourage this interaction, in that the storage area for coats and outdoor wear has a generous amount of room to hold short conferences away from the main focus of activity in other rooms.

The centers are required by law to conduct at least two parent meetings per year. ${ }^{77}$ Centers observed conducted from four to eight such meetings per year, al though attendance at such meetings was sparse. The most successful meetings were those which promoted a party-like atmosphere for parents and child care for the chlldren during the meetings. Parents were found participating directly in the care of chlldren at the center twice during the course of the observations. In the first instance, it was sald that the mother was at the center walting for a conference with the director regarding behavior problems with the child. Staff of the center were quite clear that this instance of involvement was quite unusual. The second instance involved a child care center in which parents had played a significant role in both its inception and its ongoing functioning. The father of a retarded child cared for at the center

77 "Child and Young Person's Act," op. cit., p. 24. 
was having coffee with the staff as we entered and proudly told of the Inception of the center and the activities of Its board of directors.

In this area, it was found that the Danes fare no better than many American day care centers in parent participation and contact. The question still remains as to whether the child care staff truly believe that both the children and themselves will benefit from interaction with parents. It was repeatedly expressed that:

(1) parents are largely intimidated by the day care center's staff, regarding them as "experts" who cannot be challenged; and (2) parents view child care, to a large degree; in terms of custodial care and are not motivated to take extra time away from their families to reap ambiguous rewards. Compounding this problem is the fact that any complaints that parents or other community members might have w1th regard to a day care center must be, according to law, taken not to a day care center but to the local chlild and Youth Welfare Committee. 
CHAPTER XIII

AUXILIARY SERVICES TO DAY CARE

In considering child care in Denmark, it would be unwise not to at least mention the existence of some of the other services Which work in conjunction with the child caring programs. The child care center, al though in many ways self-sufficient, does not operate in a vacuum.

\section{I. " THE FAMILY GUIDANCE COUNSELOR}

A review of the historical development of preventive care for children in Denmark reveals two important shifts in policy over time. The first preventive care program for children could perhaps be considered the law passed in 1963 which decreed that the father of a child born out of wedlock is liable to contribute at least one-half of the costs incurred in supporting the child until he is ten years of age. A further provision indicated that the State must assist the mother with the collection of this support. In 1888 , a law providing for automatic, compulsory supervision of all foster children considerably extended-preventive care for children. In 1923, this automatic, compulsory supervision was extended to all children born out of wedlock and all children from separated and divorced parents, if the father's (or motheri 's) support was paid in advance by the kommune. This program of compulsory supervision directed to specific types of families (i.e., guidance tied to the 
provision of economic help and directed primarily to the socially or economically "needy" family) continued until 1964 when, following an extensive review by the State, a new law was passed. The new law was a significant departure from the past in several ways. All automatic, compulsory supervision of children, other than those in foster care, was abolished and replaced by a new family guidance program. The new program differed from the old in that participation was completely voluntary and in that it was directed to any family with children under eighteen years of age. This change was the result of two observations: (1) that guidance to all famflies within a certain category resulted in too much supervision of families who were in no real need of such supervision; and (2) that many families in real need of guidance did not fit into any category specified and were unable to receive help.

The family guidance provided by the Child and Youth Welfare Committee is a preventive service, implying an offer of continuous guidance and support to families with children on the general principle that preventive services for children and young people should take into account the general family situation. 78

Family guidance is intended for families who, without being In iate need of any actual action on the part of a particular service, are faced with an emergency (i.e., an unmarried mother or father, a widow, or divorced person is the sole support of a family, or one of the parents is unable to contribute to the up-

${ }^{78}$ Fact Sheet Denmark, "Treating the Troubled Family," op. cit., p. 1. 
bringing and care of their children for reasons of 111 ness, mental disturbance, absence from the home, national service, or detention in a penal institution). Cohabiting parents may also be in need of family guidance due to long illness, mental retardation, or alcoholism.

Family guidance, while provided primarily at the request of the individual family ( 89 percent initiate contact themselves), may be offered by the Child and Youth Welfare Committee when it becomes aware that a family is in need of services from such a service. $^{79}$ This may occur in the course of its own activities or in its cooperation with other kommune or voluntary institutions and authorities, such as the Social Welfare Comittee, a school, physician, day care center, visiting health nurse, or the police.

In practice, family guidance consists of general practical guidance primartly through visits to the home (although group counseling is available where the need is indicated) and involves such areas as the care and upbringing of children, schooling and recreational activities, vocational counseling, etc., as well as budgeting and the practical organization of housekeeping. Where assistance from public authorities or institutions is necessary, the family counselors may call attention to the available facilities and arrange for the initial contact, where necessary.

Due to a shortage of trained social workers, the family guidance counselor may be drawn from a number of aligned professions.

79 Mars den Wagner and Mary Wagner, "Family Guidance in Denmark" (Washington, Office of Child Development), p. 4. 
including nursing, education, and home economics. A short-term supplementary training course (400 lessons) in counseling technique, the social services, subjects of family law, psychology, paedigogics, housekeeping, etc., is provided for those who are not qualified as social workers or similarly trained.

Each Child and Youth Welfare Comittee decides for itself the extent of preventive services. Every kommune is required to have a program of famtly guidance but is not required to meet any spectfications; hence, the quality of services varies widely. In small, rural kommune, a member of the Child and Youth Welfare Committee staff may be arbitrarily assigned the role of famlly guidance counselor for the kommune.

In order to encourage the local authorities to provide a quality famlly guidance service, the Minister of Famtly Affairs has been empowered to recognize such services and retmburse the kommunes for seven-tenths of the cost of such services, which are in accordance with state specified standards.

\section{MOTHER'S HELP}

As noted previously, it was realized long ago that something should be done to help the unmarried mother, for she was in a most conspicuousiy difficult position. With this in mind, the first maternity hospital, where unmarried women could give birth under safe and discreet conditions, was founded near the end of the eighteenth century. 
Following the legislation of 1763 , deemling the father's 11 ability to the support of his children borm out of wedlock, in 1888 Denmark went further and introduced an important and novel law giving the mother the right to have the father's maintenance payment in advance by kommune authorities ás soon as it falls due, thus making the mother independent of the father's willingness or. ability to contribute.

In reality, though, it was acknowledged that the position of the unmarried mother was still a difficult one. Cases of infanticide and suijcide were not uncommon among such unwed mothers. It was as a result of this situation that a group of interested people began to work on a program of relief for these women and their chlldren "in a way "and to an extent which the circumstances in each case require." 80

This gave rise to the organization of Mother's Help (muthrahjelpen, also referred to as Mother's Aid in other sources): Mother's Heip:operated for many years as a voluntary organjzation dependent on private contributions. It provided accommodations for pregnant women and mothers with infants, often in nursing homes run by the association. It made arrangements for nursing care and adoption, and this helped fight the rise of unscrupulous speculation in adoptions which was prevalent at the time. Furthermore, Mother's Help recognized that part of its work was to give legal aid in

80 Vera Skalts and Magna N\&rgaard, "Mother's Aid in Denmark" (Copenhagen, Det Danske Selkslab, 1973), p. 3 . 
affillation cases and grant loans to mothers, particularly before their cases were settled. In 1936, the organization was expended to include medico-social considerations, giving unmarried pregnant women access to pre-natal health control. In this way, one may see that Mother's Help played an active role over a broad spectrum of services to women and children. Subsequently, in a manner typical of Denmark, the services provided by Mother's Help were deemed so essential that the organization was absorbed by the State under the Ministry of Soctal Affalrs and expanded from serving on the Copenhagen area to a network of fourteen offices serving the entire country.

Today, Mother's Help serves about 50,000 women annually. Of these women, 40 percent are married and 60 percent single, divorced, separated, or widowed. Eighty-five to 90 percent of all unmarried women and nearly 20 percent of all familles are in touch with Mother's Help at some time. ${ }^{81}$

In 1971 there were 75,561 children born in Denmark. Of these, 9,344 were children born out of wedlock. ${ }^{82}$ The term used to denote unmarried mothers in Denmark is "lonely mothers." It is felt that this term carries a more open attitude toward these women and acknowledges that they may be unmarried out of choice. Although

$$
\begin{aligned}
& 81 \text { Ibid., p. } 4 . \\
& 82 \text { Ibid., p. } 47 .
\end{aligned}
$$


the problems encountered by lonely mothers may be great, there is little social stigma attached to the situation.

Generally speaking, it is the purpose of Mother's Help to meet the needs of social services for pregnant women, single mothers, or families with small infants who may apply to the center to discuss problems and, through cooperative work, try to solve them. This is achieved partially through counseling, through economic support, and possibly through a stay at a convalescent or other type of home.

All pregnancies in Denmark are registered with Mother's Help by the physician who makes the diagnosis. 83 In addition, the physician is required by law to report to Mother's Help if the pregnancy is out of wedlock. He is simflarly required to refer a pregnant woman to the nearest Mother's Help center if he knows her to have social, legal, financial, or personal problems. This procedure assures the highest level of case finding of women needing services. Close to half of all women in Denmark eligible for the program come in contact with the center.

Among its wide range of services, Mother's Help provides for housing of lonely mothers. In Copenhagen, the offices of Mother's Help are adjoined by a large apartment complex reserved for such mothers. The apartments serve the purpose of providing the lonely mother with housing at reasonable cost in conjunction with a variety

${ }^{83}$ Mary Wagner and Marsden Wagner, "Health Visiting in Denmark" (Washington, Office of Child Development), p. 2. 
of services, subsequent to the birth of a child. The aim is to stabilize the lonely mothers' situation in order that they may eventually reintegrate effectively into the commuity.

Since the greatest part of the mothers residing in these apartments are either working or attending school, child care is provided at the complex. In discussions with the director of the child care center, it was noted that this center differs from others in the acknowledgement that the center exists not primarily for the children but as a service to the lonely mothers who are attempting to stabilize their lives.

\section{III.. THE VISITING HEALTH NURSE}

In 1928, Denmark, alarmed to find that their infant mortality rate was higher than that of Sweden and Norway, started a Small experimental program with the aid of a private American foundation. Four nurses began visiting infants in their nursing districts in the infant's own home. The visits were free of charge, and all infants were seen regardless of the family's income. 84

After six years of this experiment, a report was made to the National Health Service of Denmark and to the legislature (Folkeeting). It concluded that the program was a success and an important aid in combating infant mortality. In 1937, the legislature responded ${ }^{84}$ Ibid., p. 5. 
by passing an act entitled "Combating Morbidity and Mortality Among Children During the First Year of LIfe." This act authorized kommunes to establish infant home visiting programs. The establishment of this new program was to receive 50 percent subsidy from the State. In 1938, the Copenhagen Kommune began the fịst ongoing program of this type. Since that time, the service has grown steadily until, at present, 259 out of the 277 kommunes in Denmark have infant home visitors.

Whenever a child is born in Denmark, the midwife responsible for the pregnancy must, by law, complete an extensive form which gives details of the pregnancy, the delivery, the medical history of the mother, and the social history of the family." This form is sent to the Infant Health Visitor for that district: If the midwife should fail to send this form, she can be heavily fined and, thus, this reporting system is virtually: 100 percent effective. The infant health visitor will make an average of twelve home visits during the year and, if necessary, may make up to twenty visits.

During the visit, the nurse welghs and measures the infant, tests the infant for phenylketonuria, and gives advice to the mother regarding feeding, sleeping, bathing, and growth and development. The nurse gives the mother a card to keep, on which is recorded all weights, lengths, developmental assessment, and problems. The nurse may give advice regarding minor illnesses such as colds or skin 
problems but refers the infant to the family doctor for more serious medical problems.

In addition to referring the infant to the family doctor, the health visitor may also refer the family to their needed services. When the program first began, the emphasis was on the physical health of the child. Now emphasis is also given to mental heal th and developmental and social problems. Consequently, infant heal th care visitors are an important source of referrals to the family guidance counselor and other services. If the infant is in a vuggestrue, the health visitor will make routine visits to the vuggestrue, where she will examine the child and discuss the child with the staff. The health visitor willalso make home visits in the evening so she may give advice to the parents. In this way, the heal th visitor is part of the whole network of services for children and works actively with many different types of child care workers.

In the past ten years, there has been a new trend in the way infant health visiting is conducted. Because of the shortage of adequate numbers of trained heal th visitors, new methods of health visiting were tried. In one rural community in Denamrk, a series of experiments showed that health visiting was most valuable for families with a first chlld and famtlies at risk, families in which ". . the children are either not quite well or are living under conditions which may influence their physical and/or mental 
development. " 85 These experiments showed that approximately 15 percent of the famrilies with infants were at risk. By visiting all infants one time, the health visitor could identify the firstborn or at-risk infant. She would then not visit low-risk infants any further and could then have time to visit the high-risk children many times and continue visiting until school age. This experiment was so successful that other kommunes began to adopt the new scheme. It is now the official written policy at the National Heal th Service, and it is estimated that approximately half of the heal th. visitors are practicing in this manner.

The number of infants covered by health visiting has steadfly increased until presently 88 percent of all infants in Denmark receive home visiting. The remaining 12 percent live in komines which have not yet established this sttll-optional service. of the 88 percent who are covered, 99.1 percent have recelved all of the required health visitor home visits. Less than 2 percent of the families have never received this service. ${ }^{86}$. It was noted in discussions with Danes that even those mothers with considerable child caring expertise welcomed the infant heal th visitor.

The implied results of this program are extensive: Among children entering school in Denmark, 95 percent are fully immunized for smallpox, and 93.2 percent had had full polio immunizations.

$$
\begin{aligned}
& 85 \text { Ibid., p. } 4 \\
& 86_{\text {Ibid. , p. } 5 .}
\end{aligned}
$$


Seventy-four percent of the children have had a full complement of well child checkups. Even considering discrepancies in 1 ts measurement, infant mortality rates represent a reflection of the level of health care of infants. In Denmark, the infant mortality rate is 15.8 per one thousand live births, a level very close to the best in the world, and considerably better than the United States. ${ }^{87}$

\section{CHILD COUNSELING CENTERS}

Care of exceptional children takes place primartly in the neighborhood child care center. Centers observed care for a substantial number of retarded, brain damaged, disturbed, and physically handicapped children. There exists very little in the way of non-residential, full day care for exceptional children. Rather, these chlldren are taken regularly, to spectal schools at intervals during the week.

Non-residential care for emotionally disturbed children is carried out in one of nine child counseling centers in the country. Therapy is undertaken while the child is still attending his regular day care center or school. Emphasis in the particular center observed is heavily on family therapy. Therapy is conducted on a regular hourly basis with extensive use of the "big meeting"

${ }^{87}$ Ib Id., p. 8. 
(multiple impact therapy), in which as many as forty of the persons involved in a child's life may be brought together in the presence of the child for as many as fifteen sessions:

It was noted at the center that two primary groups of children were treated at the center. The groups were five- to seven-yearold aggressive boys and ten- to twelve-year-old children of both sexes with interpersonal problems in relattonships. In comparing common emotional disorders between children in the United States and Denmark, however, Dr. Ruth Iverson found that Danish children exhibit fewer behavioral disorders and more somatic disorders, anxiety neuroses, and hysterical states. One in every four Danish children is enuretic. She theorized the cause of this trend as the heavy emphasis on the development of the super ego in Danish children.

The child counseling center observed was making plans to establish only the second non-residential day treatment facility for the emotionally disturbed child. - Previously, children unable to function in the traditional classrom environment were either simply removed from school or placed in a residential care facility. 
CHAPTER XIV

DEALING WITH POVERTY AND RACISM

Long before arrival in Denmark, it was evident that there would exist a problem in observing a balanced number of centers in Denmark. In observing centers, one was aware of being directed primarily to the "best" centers, which were representatives of smoothlyfunctioning centers which represented current trends in day care.

It becomes apparent, after investigating social and economic problems in Denmark, that poverty, as it is known in the United States, simply does not exist in Denmark. The system of social welfare assures that no person in Denmark need go without food, housing, medical care, or any other basic necessity. Substandard housing does exist in Copenhagen, but there is much resistance to removing it, as such structures house primarily the elderly, who may well have resided in the same location their entire 11 ves and would simply refuse to move, or young people for whom this inexpensive housing represents the opportunity to save money either for schooling or to obtain the money necessary to purchase a home.

Although economic poverty may be argued not to exist in Denmark, social poverty is quite evident. Near downtown Copenhagen is the Vesterbrogade area where, although there is no starvation, the lower class lifestyle continues with most of the soctal implications of poverty: slum dwelling, poor diets, dirt, perhaps unusual $11 \mathrm{fe}-$ styles (prostitution and alcoholism), people cluttered on doorsteps, 
and a high population density. It was felt that there was a great deal to be learned through the observation of work with children in this "soctal slum." This desire was expressed to the paedigogues to see centers in operation in such areas.

Only after lengthy observations of the initial center observed, which was located out of the central core of the city in a large, modem apartment complex, was it realized that both the center and the apartments were part of an urban renewal project. Children from the central core area of Copenhagen whose families were to be relocated were brought to this center. Apparently there were substantial problems with these children at the program's onset five years ago. An example cited was that the chlldren were totally unaware of the use of a bathtub, and the implication was made that they used it as a urinal. However, in subsequent years, with the relocation of families, the children have adjusted to the point that they are indistinguishable from any other suburban children. The paedigogues seemed plased in aiding in this adjustment.

The desire was expressed to observe a center which was experiencing difficulties in its program. One paedigogue stated that a friend of his worked at a center which both served poor children and was experiencing difficulties in carrying out its program. Contact was established with this friend, who drove us to the center.

On driving to the center, we were told that the center served primarily a gypsy population. We were driven by reclaimed land, 
the former site of a refuse dump, that the Danish government had set aside for newly-immigrated gypsies. It was said that the gypsies had been driven from the other Scandinavian countries but that, although they were not welcomed in Denmark, the Danish government felt an obligation to accept the gypsies and make some, al though meager, provisions for them. Hence, newly-arrived gypsies camped for months at a time while awaiting housing openings. Arriving at the community served by the child care center to be observed, we found it to be a small village of former army barracks. Staff of the child care center stated that the barracks were remnants of the Nazi occupation of Denmark during the second world war. The housing itself was as stark as expected but was surrounded by a large amount of vegetation and foliage. It was crossed by pathways rather than streets and had a seldom-used park within the complex. The homes are all owned by the Copenhagen Kommune. Although technically open to all, only gypsies are welcomed by the community, and the non-gypsy population is virtually nil.

The center was actually both a bprnehave and fritidshjem, each housed in its own barrack. The centers each had separate outdoor play areas divided by a low fence. The staff apologized for the lack of play equipment, which was sparse in comparison to other centers observed. It was explained that the children cared for at this center were particularly destructive, and the center was financially unable to replace all of the broken equipment. 
Observation confirmed a noticeably higher level of destructive behavior.

Shortly thereafter, the situation was discussed with the director of the bprnehave and a staff member fluent in English. The conversation turned immediately to the backgrounds of the children. About 75 percent of the children served by the center are at least of partially gypsy descent. The staff talked of the gypsies as "inherently treacherous." The feeling among those participating in the discussion was that these children would almost inevitably grow up both to roam and steal. It was said that the center's job was to counteract this trend, although there was little optimism that their lifestyle could be significantly altered.

It became rapidly apparent that the staff, and Danes in general, al though willing to accept gypsies into the country, hoped they would conform to the "Danish way of life." Housing was noted as a particular problem with gypsy families. A part of the system of bellefs of the gypsies is the idea that it is "unclean" for a man to live above a woman. In the metropolitan Copenhagen area, housing, espectally low-cost housing, is in the form of apartments.

The community itself is located directly across from a large sports arena. A developer has proposed that the gypsy community be removed to allow for the construction of a hotel, restaurant, and gas station complex. The staff of the center is particularly fearful of this proposal for, al though both the center and the families can be relocated in the area, the apartments avallable 
cannot conform with the existing lifestyle of the people. The director of the center predicted that, should the gypsies be forced to move into apartments, 50 percent would commit suicide.

Exaggerated as this projection might be, it is obvious that relocation would do substantial damage to those famtlies who have been in Denmark for many years and would not choose to relocate.

There is considerable distance between the gypsy community and the Danish communtty at large. Three years ago there was a complete turnover of staff at the center due to the inability to cope with the gypsy community. When the new staff arrived, they found that materials were being stolen from the center in the order of twice a month. If the police were called in, two problems resulted: (2) The police either refused to follow up because they feared the community, and particularly the gypsies' reputed skill in the use of knives, or they would simply make a superficial Investigation, solving nothing; and (2) the communtty became all the more alienated at having "outsiders" called into the communfty. At a later point, the leaders of the community were uncovered, and relations were strengthened with them. Subsequently, when materials were stolen from the center, the community leaders were contacted, and the material was returned without investigation. Nothing had been stolen from the center in the past several months, and community ties had been strengthened.

The staff of the bormehave considered that their major success had been in the area of community acceptance. Cited as an example 
of this is the fact that most families, when they needed to come in contact with the government, contacted the center first to help smooth the way. Nonetheless, the attitude of the staff may best be characterized as one of "benevolent paternalism." The staff aims primarily at acclimating the gypsy children to Danish customs and mores rather than building an appreciation of the gypsy culture which, it is feared, will only cause them trouble. Whereas authority and control had been only minor topics at other centers, it was of primary importance at this center, with these children. Initially, it was said, the staff shies away from direct confrontations with gypsy children because the child may subsequently close themselves off from the staff. But later it was noticed that a substantial amount of physical control was exerted on the children. This was the only center observed where children were physically held in order to control them. This was the only center where chlldren were forced to eat, due to the fear that they would not recelve a proper diet in any other way. Finally, there was almost nothing in the way of educational material. The children's primary form of play consisted of gross motor exercise. One could not help but note that this presented a particular problem due to the cramped facilities during the winter months. The director of the center had attempted to obtain special funds for the care of these children through the kommune but had been, thus far, unsuccessful. 
The second "poor" center observed had been noted early because of its avowed..communist philosophy. The center was located in the center of Copenhagen's deprived Vestebrogade district. It was constructed on a site that had been originally occupied by apartments scheduled to be destroyed. A group of young people adhering to communist philosophies had moved into the abandoned buildings to establish a commune and refused to move. A stalemate with the government ensued until an agreement stipulating that the Copenhagen Kommune would establish a child care center, headed by a woman in the group, was agreed upon.

Since that time, five centers have been established on the site. Four are bqmehavn, and one is a recreation club. Each center operates independently, and each staff carries a slightly different political or social orientation, al though each may be described as "radical." It should be noted at this point that these are municipal, kommune-operated; not private centers. The quality of care dispensed through these centers was generally poor by the standards established in other Danish centers. In the recreation club, the functions of the club were handled by weekly meetings with the children, at which time they would choose how the money was to be allocated. The result was that the children gave a great deal of the money to various radical causes and allocated much of the rest to giving parties to which the entire community was invited. Physical facilities at the club were almost nonexistent. By far the most 
used room was a small temporary buflding in which the children talked and listened to music for most of their days.

The center was mentioned to many of the Danes subsequently encountered, and their reaction varied widely. Most of the paedigogues were aware of the program and approved of $i t$. They noted that the center served a particularly difficult segment of the population which most would care to forget. They noted that what may seem to be mindless activity in comparison to other centers is reaching out to these chlldren at a level at which they are able to relate. Others talked to, primarily out of the field of chlld care, were unaware of the existence of such a program and were outraged by $i t$.

Finally, one should note the existence of at least one program expressly for black and ethnic minority groups in Denmark. The organization, known as "The Afro-American Community in Denmark," was found operating a weekend center aimed primartly at bringing together the black chlldren in Denmark in order that they might come to realize and appreclate their heritage. Although Danes are particularly receptive to blacks, there are only a handful in the entire country. It was interesting to note that al though the Afro-American center was the only center observed serving any black children, virtually every center observed had a black doll prominently displayed. 
CHAPTER XV

CONCLUSION

In conclusion, we must return to our origina] question: What relevance does Danish day care have for the development of child day care in the United States? Our original plan had been to study Danish day care with the hope that it would, indeed, have implications for the United States but found that the Danish experience with chlld care must be seen within the cultural context. The relevance to the United States is complex and often obscured. Caution is called for in making any judgments.

It should first be noted that the United States does share a considerable amount of cultural, economic, and political heritage with Denmark. Both represent affluent, industrialized, democratic, and western societies. Indeed, the type of care provided in most day care centers in Denmark shares similar theoretical concepts of care with many: "progressive" developmentallyoriented centers in the United States:

We shall note several differences nonetheless:

1. The purpose of day care has evolved in Denmark in such a way. that it is seen less in terms of a necessity to maternal employment and more in terms of its benefits to early childhood development. Maternal employment is lower in Denmark than in the United States. Whereas most children in care in the United States remain at home or are in private family day care arrangements and most group care 
is proprietary, most care in Denmark is carried out in non-profit group centers.

2. One may note the significance of the current institutionalized decentralization of day care in Denmark. Local initiative in day care has been institutionalized and increasingly invested in the local Child and Youth Welfare Committee. In the United States, initiative in day care has yet to become institutionallzed at any level.

3. One must acknowledge that day care, and particularly government intervention in day care, has evolved over a considerably longer period of time in Denmark. State financing and supervision has been in effect since the beginning of the twentieth century. 4. Danish day care is surrounded by and increasingly coordinated with a large array of other social services, such as Mother's Help, family allowances, and family guidance services. Particularly impressive is the $p l$ an to coordinate all social services in neighborhood facilities.

5. The Danes represent a more culturally unified population than the United States. Attitudes toward child rearing practices are more homogeneous in the small state. This was demonstrated in dealings surrounding toilet training, naps, and meals.

6. Day care in Denmark is economically secure. The development of day care in any particular area is determined, at least in theory, by the need for care and not the availability of financtal backing. 
7. Day care in Denmark is not under direct pressure to solve a non-day care problem (i.e., day care is not used as a tool to get mothers off welfare or to bring impoverished children to acceptable academic leve1s, as in Head Start). Day care in Denmark is "preventive" rather than compensatory and is accepted as such.

The effectiveness of Danish day care is difficult to demonstrate, due to the fact that the Danes put little emphasis on statistical proof of the effectiveness of any particular theory. Danes are apparently less compelled to justify their programs and substitute a sense of practical feasibility and application of theory. This presents a difficult methodological problem for those who choose to study Danish day care.

This de-emphas is of empirical study has influenced the structure of this study. Much of the information acquired in this thesis has been based on the informal interview and participant observation. One way to measure the effectiveness of Danish day care would be through an instance which was observed and felt to be exemplary of the Danish attitude toward early childhood socialization in the day care setting.

We were visiting a b/rnehave with mixed age groups. The children ranged in age from four to seven years. The day was warm, and most of the children and all the staff were outside. Inside, a small group of children sat painting with water colors. A four-yearold boy with poor vision and muscle control sat at one corner of the table with an older girl next to him. The boy was busily 
painting so that he finally over-moistened the paper, and it began to tear with each stroke. The boy's frustration grew until the older girl noticed what was happening. While the other children watched, she took the torn paper, folded it in two, moved it to the side, and placed a clean sheet of paper in front of the boy. The chlldren all returned to their individual painting. No one teased the boy. None made critical remarks.

An observation such as this cannot be statistically evaluated but can evoke a personal response and can be practically evaluated in light of many other such instances. It represents qualities which the Danes hope to instill in their young.

The seven points noted earlier in this chapter are focused on the institutional aspects of day care. They call for caution in promising that principles of Danish day care may be successfully implemented on a wholesale basis in the United States. Caution extended, the Danish way for caring of children does have a bearing on our system:

1. The incorporation of the integrated age group holds many possibilities. It allows for the limitation of age-specific activities and permits a child to develop at his own rate with less peer group pressure. The older children learn responsibility; younger children learn more mature patterns of behavior via modeling.

2. The attitude toward chlldren in Denmark is certainly relevant to our culture. The two Important concepts stressed in Denmark 
are trust and independence. Danes have trust in their capability in handling children. They also strive to incorporate independence, which carries connotations of independent thought and activity, rather than freedon from responsibility, particularly responsibility to those about them.

3. The quality of care is inevitably tied to the cost of care. The Danes have chosen to invest heavily in their children's institutions. The resultant sys tem of care is impressive.

4. In regard to seminarium, mention was made of the value of specific training in child care. Education for day care as conceived and carried out in Denmark is a primary requisite to the Danish system of care.

Day care in Denmark is a long-standing tradition in a country with a history of social consciousness. Danes demonstrate that many concepts thought of as impractical in the United States, such as large-scale government subsidy, is feastble given appropriate conditions. In acknowledging that Danish day care as a general system is far more advanced than in the United States, we may examine day care in Denmark as a lesson in social policy. 


\section{REFERENCES}

Biber, Barbara, Preschool Education, New York, Bank Street School of Education, 1964.

Brickman, W11liam W., Denmark's Educational System and Its Problems, Washington, D.C., U.S. Dept. of H.E.W., 1960.

Bronfrenbrenner, Urie, Two Worlds of Childhood: U.S. and U.S.S.R., New York, Simon and Schuster, 1972.

"Building and Environment," Denmark Review, Copenhagen, 1972.

"The Child and Young Person's Act of 1964," Copenhagen, Ministry of Social Affairs of Denmark, 1964.

Danmark's Statistik Arbog 1972, LXXVI, Copenhagen, Socialstyrelsen planloegnins fdelingen, 1973.

Dixon, Cybil, Society, School and Progress in Scandanavia, New York, Permagon Press, 1965.

Emlen, Arthur, "Day Care for Whom?" in Children and Decent People edited by Alvin L. Schorr, New York, Basic Books, 1974.

Gil1, H. "Family Welfare Measures in Denmark," Population Studies, VI, 1952-53.

Howell, Mary C., "Employed Mothers and Their Families," Pediatrics, LII, August, 1973.

Iverson, Ruth, "Impressions of Differences Between Danish and American Child Rearing and Child Psychopathology," unpublished paper, 1959.

Keyserling, Mary Beth, Windows on Day Care, New York, National Council of Jewish Women, 1972.

Prescott, Ellzabeth, Day Care as a Child Rearing Environment, National Association for the Education of Young Children, 1972.

Press and Cultural Relations Department of the Ministry of Foreign Affairs of Denmark, Fact Sheet Denmark, "Living Standards". 
Press and Cultural Relations Department of the Ministry of Foreign Affairs of Denmark, Fact Sheet Denmark. "Treatment of the Troubled Family".

Skalts, Vera and N\&rgaard, Magna, Mother's Ajd in Denmark, Copenhagen, Det Danske Selkslab, 1973.

Spitz, Rene A., "Hospitalism: An inquiry into the genes is of psychiatric conditions in early childhood," Psychoanalytic Studies of the Child, I. p. 53-74.

"Study Finds Ominous Results From Family Day Care," Report on Preschool Education, (August 22, 1973), p. 2.

Thrane, Egil, Education and Culture in Denmark, translated by Harold Young, Copenhagen, G.E.C. Gad, 1958.

Toft, Alfred, Care of Children and Young People, Copenhagen, Ministries of Labour and Social Affairs, International Relations Division, 1970.

Wagner, Mary and Wagner Marsden, "Day Care Programs in Denmark and Czechoslavakia" in Resources for Decisionmaking in Day Care, Washington, D.C., Office of Child Development, 1970.

Wagner, Mary and Wagner, Marsden, "Child Advocacy in Denmark: Seventy Years with This 'New' Idea," Washington, D.C., Office of Child Development.

Wagner, Mary and Wagner, Marsden, "Family Day Care in Denmark" Washington, D.C., Office of Child Development.

Wagner, Mary and Wagner, Marsden, "Group Day Care in Denmark: A Century and a Half of Experience," Washington, D.C., Office of Child Development.

Wagner, Mary and Wagner, Marsden, "Health Visiting in Denmark" Washington, D.C., Office of Child Development.

Wagner, Mary and Wagner, Marsden, "Training Group Care Workers in Denmark," Washington, D.C., Office of Child Development.

Welfare Administration, Children's Bureau, Guide Specifications for Positions in Day Care, Washington, D.C., U.S. Dept. of Health, Education and WeTfare, 1965. 
APPENDIX

\section{SAMPLE OF DAILY LOG ENTRY}

July 11, 1973. Gerbrantsvej Bфmehave

"Doris from the Store Krog Bomehave had told us of a friend who worked at an older, more established center in the area. She phoned, and we were able to visit the center that day. It is a center built independently of any apartment complex and surrounded by a high wooden fence. Inside, altbough the center was not as large as each section of Store Krog, there was a large play area and many large trees. At one side was a rather small wooden building which housed two classrooms, a small office, a kitchen, a single bathroom, and an entry area lined with lockers for the children's outer clothes. It was of note that particularly with summer, the staff room was not used as such but was used as a napping area for the children because of the lack of space otherwise in the building. Again, hanging all about the rooms were painted egg cartons (which appears to be the most popular form of children's art). The room was quite cluttered by American standards. There was a wealth of things for the children to do inside. I am reminded of the long Danish winters, during which the chlldren must spend a good deal of time inside. A few of the girls were inside using a curtained-off area to play dressing up. There was a large cabinet open from which 
clothes had literally burst and ended up in a large pile on the floor. Most of the children were, however, outside on this brisk and partly overcast day.

In the center of the play area was a sandbox which had been divided into two sections. One section had been covered with a tarp and filled with water, but today was cold enough that the children were not allowed in. At times during the day they splashed each other (this was stopped) or played with sticks and a fishing net in the water. Next to the sandbox-pool was a swing, again made from tires. This was used by the children most of ten when they could sit in the lap of a staff member and swing. There are thirty-two children, six staff, a director, and a number of trainees. Two of the staff members plus the director have gone through full three-year training. . .

We later talked of the type of children they had in the center, and it was said that they were primarily "normal" and without dramatic problems. But it was also noted that there was an emphasis placed on keeping physically and emotionally handicapped children in regular day care arrangements where posstble. It was particularly noted that, during the winter months, a speech therapist comes to work with some of the children. Children with other handicaps may spend part of the day in special training schools. A psychologist is available to the center for consultation on an as-needed basis. We asked what kind of problems he had been called in for. It was noted that a psychologist had been called in only once in the past year. . ." 
June 29,1973

"While seated in an outdoor cafe in front of the central railroad station; I observed a mother with her three well-dressed male children. All the boys were dressed in denim suits. There was a dol1. The ages were approximately three, five, and seven years. The four entered the eatery area. The table they chose had only two chairs. Without any verbal exchange, the eldest boy went to other tables and brought back the two needed other chairs. The two younger boys were seated. The mother went to the stand to get polser (sausage simtlar to a hot dog): She made some communication with the children, and all agreed (probably about type of food wanted). The mother returned to the table with the boys; they began to eat. She then brought her own food to the table.

The middle boy was the-first one finished. He got up and went to the garbage, and then back to his seat. The eldest child then did the same; he was given the youngest's garbage and discarded it. All three boys sat and waited for their mother to complete her pdiser.

The mother handed the youngest boy a napkin. He wiped his own hands and played with the napkin. First he opened the napkin up, and then (he) crimpled it and finally tossed it behind him into the garbage basket. The eldest folded his napkin and got up to throw it out. The youngest watched intently. 
The mother finished eating. Everyone remained seated. The youngest asked his mother for something. She took a roll of candy from her purse and handed all three children a piece of candy; she had a piece, too.

The mother lit a cigarette, and the three children continued to sit, however getting fidgety and looking bored. The middle boy had gotten up while holding on to the awning. There was some conversation going on during his movement. He moved to the table, shifting weight onto the eldest's chair and on to the table. He walked around towards his mother. Others have remained seated.

The middle boy found some stale bread. He picked it up and walked around throwing the bread to a pigeon. A smile and eye contact were exchanged between mother and middle son, as the pigeon began to eat. The middle boy got more bread and threw it to the pigeon. He then began throwing it at the pigeon. At this point, his mother intervened by saying his name, softly but stemly, and he retumed to the table.

The four were then ready to leave. The youngest took a few steps" toward the pigeon area. He squatted and clapped his hands. The mother verbally notified the children that she was ready to go. All got up and left together."

\section{Ellane Kibel}

July 4, 1973

"Shortly after we arrived at the Store Krog Vuggestrue, I was standing at the end of a long hallway and observed a young 
mother bringing in her infant of about eight months. The infant boy was large and chubby. There were some teachers and staff members at the end of the hall, with carriages and some children. The mother (about age 23) carried the infant; leaving his carriage in the outdoor storage area. The mother handed the baby over to one of the paedigogues. The two women conversed, while the child remained complacent.

When the mother left the hallway, the child watched. He was then handed to another young female paedigogue. The mother passed through the doors to the outside; no overt emotional distress was demonstrated by the child."

Ellane Kibel 
INSTITUTIONS

VISITED

Afro-American Community in Denmark Day Care Program B $\phi$ rmehospitalet I Vangede

Broparken Integrerede Institutioner

Broparken Radivngscentret for borne og unge

Copenhagen Kommune Dagpleje

Danmark!s Paedigoske Bibliotek

Ellestykeet Børnehave and Fritidshjem

Estladnesgade Vuggestruen

Estl andesgade Pension

Froebel Bornehave Seminarium

Gerbrantsvej $B \not$ mehave

Hillerød Seminarium

Hundegarten Bdrnehave and Fritidsklub

Kennedygarten Bornehave and Vuggestrue

Lilleskole

Mutrahjaelpen Bornehave

Ringertoften Halday $\mathrm{B}$ mmehave

Socials tyrelsen

St. Magelsby's Fritidsklub

Store Krog Bømehave and Vuggestrue

Tingb jerg Scrammelespladen

Tuborg Bornehave and vugges true

Vartov Bornehave 
CHILD. CARE INSTITUTIONS IN DENMARK AS OF DECEMBER 31, 1972

Recognized Day
Care Institutions

Vugges truen

Family Day Care programs

Bdrmehavn

Fritidshjem

Integrated

Instí tutions

Free Time and 01der

Children's Clubs

Scrammelespladen

Other types of care

Sub-tital

Private Day Care

Bomehavn

Pl aygrounds

Sub-total

Total
Number of

Institutions

429

180

1,913

348

4

245

55

84

3,258

137,903

63

39

102

3,360
1,396

768

$$
2,164
$$

Number of Places

15,199

17,416

83,123

20,565

400

140,067 
SURVEY OF CHARGES AT CENTERS OBSERVED

(Partial Sample)

\begin{tabular}{lllr} 
& Vuggestruen & Bqdmehavn & Fritidshjem \\
\hline \multirow{2}{*}{ Btoparken } & $390 \mathrm{kr} / \mathrm{m}$ & $290 \mathrm{kr} / \mathrm{m}$ & $180 \mathrm{kr} / \mathrm{m}$ \\
& $\begin{array}{l}160 \mathrm{kr} / \mathrm{m} \\
\text { (half day) }\end{array}$ &
\end{tabular}

Afro-American Center

Tuborg

Hundegarten

Kpbenhaun Dagpleje

St. Magelsby

Ellestykeet

Tingblerg

Scranmelespladen

Muthrahjaelpen
$76 \mathrm{kr} / \mathrm{m}(\max )$

free (under $20,000 \mathrm{kr} / \mathrm{yr}$ income)

$18 \mathrm{kr} / \mathrm{w}(20-30 ; 000)$

$27 \mathrm{kr} / \mathrm{w}(30-40,000)$

$45 \mathrm{kr} / \mathrm{w}(40,000+)$
$40 \mathrm{kr}$ (initiation)
$5 \mathrm{kr} /$ week other

$20 \mathrm{kr} / \mathrm{m}$

$\begin{array}{cc}180 \mathrm{kr} / \mathrm{m} & 100 \mathrm{kr} / \mathrm{m} \\ 35 \mathrm{kr} / \mathrm{w} & 20 \mathrm{kr} / \mathrm{w}\end{array}$

$12 \mathrm{kr}$ (initiation)

$10 \mathrm{kr} / \mathrm{m}$ 
FEE

RANGE

Vuggestruen (maximum payment)

45-91 kroner/week

(\$7.89-15.96/week)

Bprnehavn (maximum payment)

35-67 kroner/week

Fritidshjem 20-40 kroner/week

Youth Clubs $10-100$ kroner/month 